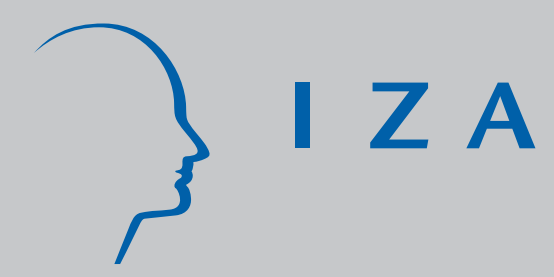

IZA DP No. 4138

Differences in Decline:

Quantile Regression Analysis of Union Wage

Differentials in the United Kingdom, 1991-2003

Alejandra A. Manquilef-Bächler

Wiji Arulampalam

J ennifer C. Smith

April 2009 


\title{
Differences in Decline: Quantile Regression Analysis of Union Wage Differentials in the United Kingdom, 1991-2003
}

\author{
Alejandra A. Manquilef-Bächler \\ University of Warwick \\ Wiji Arulampalam \\ University of Warwick, \\ Oxford Said Business School and IZA
}

Jennifer C. Smith

University of Warwick

Discussion Paper No. 4138

April 2009

IZA
P.O. Box 7240
53072 Bonn
Germany

Phone: +49-228-3894-0

Fax: +49-228-3894-180

E-mail: iza@iza.org

\begin{abstract}
Any opinions expressed here are those of the author(s) and not those of IZA. Research published in this series may include views on policy, but the institute itself takes no institutional policy positions.

The Institute for the Study of Labor (IZA) in Bonn is a local and virtual international research center and a place of communication between science, politics and business. IZA is an independent nonprofit organization supported by Deutsche Post Foundation. The center is associated with the University of Bonn and offers a stimulating research environment through its international network, workshops and conferences, data service, project support, research visits and doctoral program. IZA engages in (i) original and internationally competitive research in all fields of labor economics, (ii) development of policy concepts, and (iii) dissemination of research results and concepts to the interested public.
\end{abstract}

IZA Discussion Papers often represent preliminary work and are circulated to encourage discussion. Citation of such a paper should account for its provisional character. A revised version may be available directly from the author. 


\title{
ABSTRACT
}

\section{Differences in Decline: Quantile Regression Analysis of Union Wage Differentials in the United Kingdom, 1991-2003*}

\begin{abstract}
Wage premia related to union membership and coverage are examined over 1991-2003, a period involving first decline, then stabilization, of unionization. Differences in union premia across workers and over time are studied using individual-level British Household Panel Survey data and quantile regression techniques allowing for endogeneity of the membership decision. Raw differentials suggest the presence of large positive membership and coverage premia that are stronger at the bottom of the wage distribution in both private and public sectors. After controlling for other factors influencing wages, union asymmetries are no longer apparent in the private sector. When endogeneity of union membership is taken into account, the private sector union wage premium disappears, indicating that individuals positively select into unions. In contrast, the public sector total union wage premium remains significant - entirely due to a coverage effect; it is stronger at the bottom among males, while for females the premium is constant across workers and substantial over the whole period, reflecting the continuing strength of public sector unions. Once we control for endogeneity, the membership premium is nowhere significant; there is no free rider puzzle in the private sector, as there is no coverage premium, but the puzzle persists for the public sector.
\end{abstract}

JEL Classification: C2, J31, J51

Keywords: union membership premium, quantile regression, endogenous union membership

Corresponding author:

Wiji Arulampalam

Department of Economics

University of Warwick

Coventry, CV4 7AL

United Kingdom

E-mail: wiji.arulampalam@warwick.ac.uk

\footnotetext{
* The BHPS data used in this paper were collected by the ESRC Research Centre for Micro-Social Change at the University of Essex and made available through the ESRC Data Archive. The authors thank Mark Bryan for help with some of the software, Gillian Paull for providing some of the data, and Blaise Melly, Robin Naylor, Andrew Oswald, Mark Stewart and lan Walker for helpful discussions. The authors also thank seminar participants at the University of Warwick, Pontificia Universidad Católica de Chile, Royal Economic Society Conference 2006 and Encuentro de Economistas de Chile 2006. Copies of the computer programs (in STATA 9.0) used to generate the results presented in this paper are available upon request.
} 


\section{Introduction}

The end of the twentieth century saw rapid changes in unionization in the United Kingdom. Both union density - the proportion of workers who are members of unions - and union coverage - the proportion of workers for whom pay is set by collective bargaining - declined substantially. This paper examines the changes in wage setting behaviour that accompanied this decline in unionization, using individual-level data covering the years 1991-2003 from the British Household Panel Survey (BHPS). ${ }^{1}$ We provide estimates of the two premia that make up the total union effect on wages: the membership premium (covered member compared to covered non-member) and the coverage premium (covered non-member relative to uncovered non-member).

This paper addresses three issues that have often been overlooked in previous studies of union wage premia due to choice of estimator and data constraints. First, we use an estimation technique - quantile regression - that allows us to examine heterogeneity in union premia across different types of worker, and in particular over the whole wage distribution. We show that aggregate unionization figures hide substantial differences in the ability of unions to retain a presence and maintain wage premia.

Second, we examine the public sector in addition to the private sector, as well as distinguishing the impact of unionization on male and female pay. Past studies have tended to focus on union effects on men in the private sector, and generally find that wage premia have declined over time; but we show that union strength appears to have held up in the public sector, where premia have been maintained, particularly for women. We show that the public sector union premium derives from coverage alone. There is no public sector membership premium, so there is a public sector 'free rider puzzle'.

1 BHPS data confirm that there was a large fall in density from $38 \%$ in 1991 to $31 \%$ in 1998 , but little subsequent change (density was $33 \%$ in 2003); and coverage similarly fell from $55 \%$ in 1991 to $48 \%$ in 1998, but recovered to $54 \%$ in 2003. British workplace data show similar declines in unionization: coverage fell from 53\% in 1990 to $42 \%$ in 1998, while density decreased from $48 \%$ to $36 \%$ (Machin 2000). 
Third, we can allow for the endogeneity of the worker's decision to join a union. If, as is likely, this choice depends in part on factors that influence wages, estimates assuming exogeneity will be biased. We confirm that allowing for endogeneity is important: once we do so, the union membership premium disappears, and along with it the private sector union pay gap. Trade unions no longer appear to influence private sector pay, where there is no coverage premium; so despite the lack of membership premium there is no free riding in the private sector.

\section{Strategy of the analysis}

Most of the studies that have looked at union wage premia have looked exclusively at conditional mean models. Departing from this convention, we use the quantile regression (QR) technique to explore patterns of heterogeneity in union wage premia. The studies that have used the QR technique in the union wage premia context (Chamberlain (1994) and Eren (2007) for the U.S.; Hildreth (1999) and O'Leary, Murphy and Blackaby (2004) for the U.K.; Blunch and Verner (2004) for Ghana), with the exception of Eren (2007), do not address the issue of endogeneity.

Unlike the conventional least squares framework that looks at the effect of union membership status on the conditional mean of the log wage distribution, the QR framework allows for differing effects of union membership status on different parts of the distribution, thus enabling us to look at the effect of membership on the location, scale and shape of the $\log$ wage distribution. Another advantage of the QR model is that coefficient estimates obtained are more robust to outliers of the dependent variable. Additionally, in the case of non-normal errors, QR estimates may be more efficient than least squares estimates (Buchinsky 1998; 89).

Why might we expect the union membership premium to be different across the wage distribution, other things being equal? Productivity of workers is an unobserved variable, 
which may depend on individual as well as workplace characteristics. Additionally, it is also not necessarily a time invariant characteristic. To the extent that high productivity workers also happen to be union members, we would expect the premium to be different across the wage distribution. QR enables us to allow for complex interactions between observable and unobservable characteristics. Note that conditional mean wage models assume that unobservables have a constant shift effect.

There is a need to distinguish between private and public sectors. As recorded in Machin (2000), the decline in unionization since 1990 was felt primarily in the private sector. According to the British Household Panel Survey (BHPS) data used in this paper, coverage fell in the private sector from $40 \%$ in 1991 to $33 \%$ in 1998, but picked up to $36 \%$ in 2003 . In contrast, public sector union coverage has remained roughly constant: $88 \%$ in $1991 ; 85 \%$ in 1998; and $87 \%$ in 2003. Our results demonstrate that union wage premia have developed correspondingly: in terms of maintaining pay differentials, unions remain relatively strong in the public sector (particularly among females and low productivity males) compared to the private. $^{2}$

The use of individual-level data enables us to distinguish the effects of unionization on pay according to gender. Historically in the U.K., unionization had always been more prevalent among male workers: in 1975 for example, membership was 66\% among men but only 40\% among women (Machin 2004, National Training Survey). But evidence suggests that the decline in unionization has been substantially more rapid among male workers, such that by 2001 there was no remaining gap between union membership rates for men and

2 Similar findings are recorded in a recent paper by Blanchflower and Bryson (2007), using a simple OLS technique to investigate U.K. WERS-2004 cross-sectional workplace data, although in the absence of control for endogeneity the longitudinal individual Labour Force Survey data they also examine indicate a continuing union membership premium in both public and private sectors. 
women (30\% and 29\% respectively; Machin 2004, using the Labour Force Survey). ${ }^{3}$ As before, to the extent that unionization is associated with a union premium on wages, there is a need to distinguish by gender. In accordance with this declining unionization gender gap, we find that unions appear to have been able to at least maintain wage premia among female workers in the public sector, whereas their ability to do so among other groups has fallen.

\section{Background}

This paper seeks to measure wage premia relating to both union membership and union coverage. An individual working in a covered workplace faces the decision whether to become a member of the union or not. Covered non-members are known as 'free riders': they obtain the benefits of union coverage without paying membership fees. In the U.K., the proportion of free riders is large. ${ }^{4}$ In 1984 , coverage was $71 \%$ whereas density was only $58 \%$; by 1998, these figures were 41\% and 36\% respectively (Machin, 2000 using WIRS in 1984 and WERS in 1998). So the total union wage premium - the difference between the pay of covered union members and non-covered non-members - can be divided into a membership premium and a coverage premium. The membership premium is the differential between covered members and covered non-members, whereas the coverage premium is the differential between covered non-members and non-covered non-members. ${ }^{5}$

In the U.K., after a settlement is reached between employers and the union, pay outcomes apply to all workers regardless of whether they are union members or not. Thus according to law there should be no membership premium, which would give rise to what has

BHPS data indicate a very similar picture: membership rates in 1991 were $42 \%$ for men and $34 \%$ for women; and by 2003, the decline in male membership had led to male density of $30 \%$ whereas female remained at $35 \%$.

4 The proportion of free riders in the U.K. is large compared to the United States or Japan (2\% and $3 \%$ respectively in 1994), but is relatively small when compared with France or Germany (respectively 86\% and 63\% in 1994) (Source: ILO Yearbook of Labour Statistics 1994).

5 The literature has discussed two versions of the membership premium, depending on whether membership is measured conditional on coverage, or unconditionally. Our measure (described in the text) is the former; this conditional measure is most commonly used in recent literature. The unconditional measure takes the difference between members and non-members, no matter whether the establishment they work for recognises unions or not. 
been termed the 'free rider puzzle': why isn't everyone a free rider? Why pay to join a union when the (wage-related) benefits of unionization can be enjoyed as a covered non-member? However, there has been substantial evidence that a membership premium exists, implying there is no free rider puzzle. Based on 1975 National Training Survey data, Stewart (1983) found a membership premium of 7\%. Lanot and Walker (1998) estimated the membership premium at 9\% using Family Expenditure Survey data from 1978 to 1986. Blackaby, Murphy and Sloane (1991) and Green (1988) both found a premium of 12\% based on the 1983 General Household Survey (GHS) data set, using different models. Blanchflower (1991) recorded a premium of 10\% using British Social Attitudes Survey (BSAS) data from 1983 and 1989. Stewart (1991 and 1995) confirmed that the membership premium remained stable over the 1980s using workplace employer survey data (WERS).

Of course, unions do not simply affect pay, and their other effects may indirectly lead to higher pay or wellbeing for union members, which could solve the free rider puzzle. Some of these effects involve observable characteristics. For example, unions reduce labour turnover (Freeman and Medoff 1984), and longer tenure among union members will result in their pay being higher than non-members'. Union members may have higher human capital levels as a result of training programs organised by unions (Booth, Francesconi and Zoega 2003). Since these factors are observable, it is possible to control for them. However, doing so does not seem to eliminate the union wage premium (see the studies cited in the previous paragraph). A second class of reason for the membership premium involves discrimination. For example, employers may discriminate against non-members in order to reduce labour costs. Clearly such discrimination is illegal and, although possibly difficult to detect, might not be thought sufficiently substantial to explain observed membership premia. A third explanation for the measured membership premium involves the existence of significant unobservable differences in characteristics between union members and non-members, such 
as motivation, ability, and/or the intention to stay in a given job, so that the decision to become a union member should be modelled as endogenous.

Some recent work has indeed found that, consistent with either reduced discrimination or proper control for unobservable characteristics or selection, the membership premium is effectively zero. Assuming a positive coverage premium, such a conclusion reinstates the free rider puzzle. Booth and Bryan (2004), using WERS data from 1998 containing information on individuals and their employers, found that the membership premium disappears when observed and unobserved workplace characteristics are properly controlled for (in particular, when workplace density is included in the set of controls; Barth, Raaum and Naylor (2000) using Norwegian data and Reilly (1996) using Canadian data confirmed the null membership premium when this is done). Blanchflower and Bryson (2004), using the Labour Force Survey (LFS) from 1993 and BSAS data since 1985, found that the positive private sector membership premium vanished and even became negatively signed when they used Propensity Score Matching to correct for selection bias. They conclude that there was no premium in 2000 for most U.K. workers.

Turning to the union coverage premium, empirical evidence has been mixed about its size and even its sign. Green (1988) found that covered workers earn $0.7 \%$ less than noncovered workers using GHS data from 1983. However, Blanchflower's (1991) results, based on BSAS data from 1983 and 1989, indicated that covered workers earn $4 \%$ more than noncovered workers. Andrews, Bell and Upward (1996) found an even larger positive coverage premium of $7 \%$ in 1978, increasing to $9 \%$ in 1985, using the U.K. New Earnings Survey (NES) data.

Some work has combined both membership and coverage premia. In a study designed to assess the impact of methodological differences for cross-section analysis, Andrews, 
Stewart, Swaffield and Upward (1998) concluded that the total union premium lies between $8 \%$ and $12 \% .^{6}$ The membership effect was found to dominate the coverage effect.

It has been difficult to establish what has happened to the union wage premium over time in the U.K. because of the lack of studies with consistent methodology and comparable data. This was noted by Blanchflower and Bryson (2004), Hildreth (1999), Andrews, Stewart, Swaffield and Upward (1998), and Lanot and Walker (1998). Furthermore, it is important to take into account that the decline in union density has not impacted all groups in society in the same way. For example, Forth and Millward (2002) found that the union wage premium was confined to individuals working in establishments with multiple unions, while Hildreth (1999) highlighted gender differences in the change in membership premium between 1991 and 1995, and also showed that the decline was asymmetric across sectors and occupations.

A further issue is endogeneity: "there appears to be a quite general agreement that union status is not exogenous" (Robinson, 1989; 639-640). Among more recent studies, Budd and Na (2000), using U.S. Current Population Survey (CPS) data, showed that correcting for selection supports the membership endogeneity hypothesis; they found the membership premium to be greater once endogeneity is corrected, suggesting negative selection, consistent with low-ability workers being more likely to join unions. Booth and Bryan (2004), using U.K. WERS data, have shown that under the assumption of exogenous union membership, a positive premium is found, but when endogeneity is taken into account this premium vanishes. Contrary to Budd and $\mathrm{Na}$ (2000), this indicates positive selection: union membership appears correlated with high ability or motivation, or individuals are more likely to become members in higher-paying establishments.

\footnotetext{
Andrews, Stewart, Swaffield and Upward (1998) replicated the methodology used by Stewart (1993), Green (1988), Blackaby, Murphy and Sloane (1991), Blanchflower (1991), Lanot and Walker (1998) and Andrews, Bell and Upward (1998) using BHPS data. Methodological differences included the following: i) differences in earnings measure; ii) the measure for union; iii) set of control variables; iv) sample definitions; v) econometric models; and vi) the mean used to evaluate differences.
} 
Other previous work has controlled for unobserved (time-invariant) individual heterogeneity using panel data methods (fixed effects), rather than instrumental variable techniques. Swaffield (2001) used the same BHPS dataset that we use, but for 1991-1996. She found that allowing for heterogeneity reduces the estimated premium at the mean of the conditional wage distribution (indicating positive selection), but it was still significant (at 56\%). Hildreth (1999), however, using similar techniques and 1991 and 1995 BHPS data, reported negative selection for females and no well-defined selection effect for males; again the membership premium in the early 1990s was found to be significant, at around $12-14 \%$. We have replicated these two studies to investigate why the premium found by Hildreth appears twice as large as that reported in Swaffield. Differences in the way the control variables are coded and in the set of control variables used account for virtually all this difference: it seems that the fewer categories used by Hildreth (for school type, occupation, industry, firm size and region) hide the variables' systematic (positive) relationships with union membership, biasing his estimates upward. We use a very similar set and definition of control variables to Swaffield, and we correspondingly find similar estimates when we use her estimation technique. Whereas Swaffield pooled data over 1991-1995 and across sectors, we find that it is important to allow for variation in union premia over time and between public and private sectors; and our estimation technique enables us to investigate union premia across the distribution of individual workers.

To address the issues of studying the impact of unions across workers and over time, we use quantile regression techniques to allow for asymmetry in the effect of unions on pay and we analyse a series of cross sections over a twelve year period, based on a representative sample of individuals. We also control for potential endogeneity in the form of self-selection into membership, conditional on coverage, using an instrumental variables technique. Very little previous work has combined all these features. 
Some previous work has used quantile regression techniques to examine union wage premia. Hildreth (1999), using BHPS data from 1991 and 1995, found that the male union premium dropped from $23 \%$ to $17 \%$ in the lowest quintile but rose slightly from $11 \%$ to $12 \%$ in the highest quintile; and that among females it dropped from $18 \%$ to $11 \%$ in the lowest quintile while it remained constant at zero in the highest quintile. O'Leary, Murphy and Blackaby (2004), using pooled LFS data from 1993-1995, found that unions have most scope for increasing earnings of workers on the very lowest of wage rates. Neither of these studies corrected for endogeneity. Eren (2007), using quantile regression to analyse the CPS, reported results without endogeneity correction that also indicate greater union impact at the lower part of the distribution; but when he controlled for endogenous membership the premium was not significant at any quantile (while numerically the estimates showed no discernible pattern); he concluded that at least some non-members were free riders.

Two recent studies that have looked at union wage premia in the private sector in Britain using data from the 1998 Workplace Employee Relations Survey (WERS-98) - a linked employer-employee dataset. Booth and Bryan (2004) and Bryson (2002) both estimate only the union wage premium that applies to workers at the mean of the conditional wage distribution. Although the WERS-98 dataset has very rich information on workplace characteristics, it lacks the variety of individual specific characteristics included in individual-level data sets like the BHPS. In addition to determining the set of control variables used, this also influences the estimation method. Booth and Bryan (2004) control for endogeneity of membership by accounting for unobserved workplace characteristics that could determine membership decisions. Additionally, they use an interval regression technique because in WERS-98, wages are coded into intervals. Using these approaches they find no significant union wage premium, although it was positive and significant under the exogeneity assumption. Similarly, Bryson (2002) finds a negatively signed but insignificant 
total union wage premium using a matching technique to address the issue of self-selection. ${ }^{7}$ Both studies conclude that the usual finding of a significant union wage premium (in a simple conditional mean model) is due to inadequate control for workplace characteristics. However, both use only a single cross-section of data, and only conditional mean estimates. Can these results be generalised to other years and other parts of the distribution? Perhaps there is other important heterogeneity that these studies do not capture. And is it the case that, with adequate controls - at the individual, rather than workplace, level - doubt could still be cast on the prior literature's finding of a significant membership premium?

Our work addresses these questions and complements the above studies in many ways. We use data from a household survey (BHPS) that has unusually rich information on variables that may play an important role in the membership decision, such as: socioeconomic status of the parents, political party support, employment status of the partner, housing tenure, whether the individual works during normal working hours, and whether there are promotion opportunities at work. These variables are used as instruments when we allow for endogenous membership. In addition, we also use as much information as possible on job and workplace characteristics. A second major way in which our study extends the previous work is in estimation via the QR framework, giving a more detailed picture of union wage premia across the entire wage distribution. Finally, rather than a single year's data, we use data that spans the last decade and so are able to describe trends over time.

\section{The econometric model}

The basic model used in this paper for the estimation of union differentials is the quantile regression (QR) model (Buchinsky 1998a; Koenker 2005). Unlike the conventional least squares framework that looks at the effect of union membership status on the conditional

7 Bryson (2002) uses the mid-point of each interval to construct the dependent variable. If the interval is very narrow, this should not make a lot of difference. 
mean of the log wage distribution, the QR framework allows for differing effects of union membership status on different parts of the log wage distribution, thus enabling us to look at the effect of membership on the location, scale and shape of the distribution.

The $\theta$ th $(0<\theta<1)$ conditional quantile of the log wage $(w)$ distribution for the $i$-th individual $(i=1, \ldots, N)$ is specified as:

$$
w_{i}=\log \left(\mathrm{w}_{i}\right)=\alpha(\theta)+\mathbf{x}_{i}^{\prime} \boldsymbol{\beta}(\theta)+m_{i} \gamma(\theta)+n c_{i} \delta(\theta)+\varepsilon_{\theta i} \quad \text { with } \quad \text { Quant }_{\theta}\left(\varepsilon_{\theta i} \mid \mathbf{x}_{i}\right)=0
$$

where $\operatorname{Quant}_{\theta}\left(\varepsilon_{\theta i} \mid\right.$. ) denotes the $\theta$ th conditional quantile of $\varepsilon$ (and $\theta=0.5$ refers to the median). We include a union membership status dummy $m$ taking value 1 if the individual belongs to a union in a covered workplace. In order to pick up the 'coverage' effect, we also include an additional binary indicator variable $n c$ ('non-covered') taking value 1 if the individual does not work in a covered workplace. Hence $\gamma(\theta)$ will measure the effect of 'membership' premium conditional on coverage; and $-\delta(\theta)$ will measure the effect of working in a 'covered' workplace, capturing the difference between covered non-members and non-covered workers. The basic equation used is of the standard Mincerian type. The full set of additional controls used is given in the Descriptive Statistics Tables in the Appendix: Tables A1 to A5.

Initially, we treat the union membership variable as exogenous, but then we treat it as endogenous, correcting for selection into membership. Wage equations are estimated separately (by sector, incorporating interactions between membership status and gender) for each year. When addressing endogenous membership, we use a variant of the two-step method proposed by Buchinsky (1998b; 2001). The first step equation is four (distinguishing by sector and by gender) reduced form probits for union membership for each year using the 
sample of covered workers only (who face the decision whether or not to unionise) ${ }^{8}$ In the second step, wage equations include the inverse Mills' ratio (calculated from the first stage probit), its square, and interactions of these two with gender. Workers in the non-covered sector were assigned a value of zero for these four additional regressors. Stata 9.0 was used to estimate all models. Standard errors were calculated by the bootstrap method using 500 replications.

\section{The data and the sample}

The data are from the British Household Panel Survey (BHPS), a nationally representative survey of households randomly selected south of the Caledonian Canal (thus the north of Scotland is excluded.). The first wave of the BHPS was conducted from September to December 1991, and the survey has been carried out annually thereafter (see Taylor 2006 for details). We have chosen to analyse the 1991 (wave 1), 1995 (wave 5), 1997 (wave 7), 2001 (wave 11) and 2003 (wave 13) data. These five waves allow us to capture trends over time. Unfortunately, we were not able to use any information from years 1992 to 1994 inclusive, as during these years the relevant questions concerning union coverage and membership were only asked if the individual had changed job. A further determinant of our choice of years was the introduction of the U.K. National Minimum Wage (NMW) in April 1999. This policy change, by raising the wage of all low-paid workers, might have altered the union premium; and its effects may have been asymmetric (Manquilef 2007). We avoid using years immediately surrounding the introduction of the NMW because the labour market will have been in a process of adjustment to the policy change. Later years - we choose to analyse 2001 and 2003 - will capture any effects (on the union premium) of the NMW.

In order to save space we have not reported the results from the first stage in this paper. They are available on request from the authors. In principle, these equations could be pooled over years, if we were willing to assume that influences on the membership decision do not change over time. 
The sample used includes all individuals at each wave who were (i) directly interviewed, (ii) aged at least 16 and under 58, (iii) in paid employment, (iv) without imputed wage, (v) not employed in agriculture, (vi) not in the army, and (vii) had non-missing values for the variables used in the analyses. However, in the particular case of parental background information, tenure and experience, where there were substantial cases with missing values, we included cases with missing data but used binary indicators for these missing values.

The coverage variable used in this paper is derived from the answer to the question, "Is there (thinking about your main job) a trade union, or similar body such as a staff association, recognised by your management for negotiating pay or conditions for the people doing your sort of job in your workplace?". Those individuals who answered "yes" to this question were then asked "Are you a member of this trade union/association?" All those who answered "no" to the first question were coded as working in the 'non-covered' sector. Those individuals who answered "yes" to both questions were classified as being union members. If they answer "yes" to the first and "no" to the second then workers were considered non-members. ${ }^{9}$

The dependent variable is the log of real hourly pay, including overtime payments (calculated at a $40 \%$ premium over base pay), in the individual's main job, deflated to May 2004 prices using the consumer price index.

\section{Results}

As discussed above, we focus on three measures of union influence on pay: the coverage premium (differential between non-members whose workplace pay settlement involves unions and those with no union involved), the membership premium (differential between union members and non-members in covered workplaces), and the total union wage premium

$9 \quad$ It is possible to distinguish a fourth category of workers, namely those who are union members outside their main job's workplace. This paper assumes that this form of membership does not affect payment in the main job, so these workers are classified according to their union status in their main job. Only a very small proportion of workers belong in this category: only 2.4\% of the the BHPS 1991 sample used here. 
(differential between covered members and non-covered workers - almost all of whom are not members).

Additionally, three variants of the $\mathrm{QR}$ analysis are presented. The first are unconditional on other variables - the raw premia. The second are conditional on other determinants of pay - the exogenous results. The third are conditional on other pay determinants and also allow for endogeneity of the membership choice conditional on coverage - the endogenous results.

Results are presented graphically so that the whole distribution can be seen. Figures 1 and 2 (split by gender within sector) show the raw wage distributions for uncovered workers, covered non-members and members. These correspond with Figures 3 and 4 which present raw membership and 'non-coverage' premia for private and public sector workers respectively, disaggregated by gender. The 'non-coverage' premium is the inverse of the 'coverage' premium: if workers receive higher wages in covered workplaces, the noncoverage premium will be negative. The non-coverage premium is shown to make it easy to see the size of the total union wage premium, which is the vertical distance between the (solid) membership and (dashed) non-coverage premia lines. Numerical estimates of premia (coefficient $\times 100)$ are given on the charts for each decile; bold implies significance at the 5\% level. At the top of each graph we show a horizontal line with (or without) dark boxes at each decile. Their presence indicates the total union wage differential is significant. Figures 5 and 6 show exogenous results, Figures 7 and 8 endogenous results.

We now summarise the findings.

\section{Private sector}

Raw results indicate that the total union wage gap is inversely related to worker ability; in other words, it does not advantage high-paid workers (both males and females) to join a union. This is also illustrated in Figure 1 (which shows wage distributions estimated by 
kernel density) where for workers earning log hourly wages of 3 (£20) or more there is no unconditional union premium. Additionally, the unconditional total union wage premium (for males and females) weakens over time but remains always significant below the median. When the total premium was large (between 1991 and 1997) and where it was large (in the lower half part of the distribution) the membership premium dominated among males; while the coverage premium did so among females - this is very clear in Figure 1. In fact, heterogeneity among workers (within a year) is only apparent in this period and for male raw membership premium (from $20 \%$ at the bottom to insignificant at the top) and female coverage premium (from $25 \%$ at the bottom to insignificant at the top). In 2001 and 2003, male and female raw distributions follow a very similar pattern. The decline in the raw total premium for workers below the median after 1997 might be related to the introduction of the NMW, which would have raised wages for low-paid workers whether or not they had union representation.

As expected, controlling for observable characteristics makes a great deal of difference to estimated union differentials. The feature of the raw differentials whereby unions particularly benefit low-wage workers disappears. Among males, at any given time, the total union effect impacts nearly all workers in the same way. Furthermore, this 'union shift' remains relatively constant over the years (at around 8\%). As in the raw figures, the total union premium is dominated by a membership premium; but rather than declining over the distribution as in the raw data, the membership premium slightly increases across percentiles once observables have been controlled for. Among females, it is only in the early 1990s that there is evidence of a larger total union wage premium at the bottom of the distribution; this is driven by the coverage premium. Towards the end of the sample the female union premium becomes insignificant. 
Once endogeneity is taken into account, the private sector total union wage premium is wiped out. We thus confirm the findings of WERS-98 (Forth and Millward 2002) that by the end of the 1990s, private sector pay settlements were no greater where trade unions were involved. Our endogenous results using U.K. data are also consistent with those of Eren (2007) for the U.S.: using State public sector union density as the instrument for membership in quantile regression, Eren finds no significant membership premium for private sector men and women. (Our exogenous QR results contrast with Eren's, however: he finds a significant premium that declines slightly over the distribution from about $10 \%$ to around $6 \%$, whereas in the U.K. we find a private sector membership premium that tends instead to rise over the distribution for men and is insignificant for women.)

We also show that proper control for factors that may influence membership decisions removes the membership premium; it is not necessary to rely on the workplace characteristics used by Booth and Bryan (2004). Because we also estimate coverage premia, we are able to go further than previous authors. Whereas they thought the lack of private sector membership premium might reinstate the free rider puzzle, we show that there is no such puzzle, as there is no coverage premium. Because there is no private sector membership premium, we must conclude that members join because of non-pecuniary benefits provided by unions that are not available to non-members.

We can describe the patterns of self-selection into union membership. The QR analysis reveals some evidence of heterogeneous selection into membership across workers (within a year) and over time (which was expected, due to the introduction of the NMW). All private sector male workers positively select into union jobs throughout the sample. Evidence from the early part of the sample that self-selection is more prevalent among low-paid men disappears by the mid-1990s. Until the late 1990s there is evidence that female union workers positively select into union jobs, and their membership attainment pattern is independent of 
worker productivity. But by the end of the sample, there is very little sign of selection into union membership among women.

Now we turn into the coverage premium (the negative of this, the non-coverage premium, is shown in the Figures). In general, among private sector males, coverage is less important than membership in generating wage premia - this confirms the findings of Andrews, Stewart, Swaffield and Upward (1998). In the early 1990s coverage has a heterogeneous impact, raising wages primarily in the lower part of the distribution. But in later years, once other factors have been controlled for, the male coverage premium is rendered insignificant. In contrast, among females, the coverage premium tends to dominate the membership premium, and to demonstrate heterogeneity in the form of a greater impact at the lower end of the distribution; although, as for men, by the end of the sample the coverage premium is much weakened.

\section{Public sector}

The public sector contrasts greatly with the private sector particularly in terms of how the observed premia have changed over time, and the effect of controlling for other factors.

Total union raw differentials are large, positive and, in general, statistically significant. Overall, over time, there is little evidence that raw union differentials have declined in the public sector. Among public sector males, the total raw premium is larger for low-ability workers and is typically not observed at all at the higher end; this is similar to the pattern in the private sector. There is some indication of compression around the time of the introduction of the NMW: at the lower end of the distribution in particular, total premia for males markedly shrank in 1997 and 2001 (note that, if attributable to the NMW, this would indicate a less widespread - but earlier - impact on public sector pay, as we might expect). Among females, the total raw differentials (dominated by the membership as much as the coverage premium) are at least as large as those for males and show no indication of 
declining over time. The female raw membership premium generally exhibits an inverted "U"-shape; and the coverage premium is stronger at the bottom.

In contrast to the private sector, controlling for observable characteristics only slightly modifies the scenario. Under exogenous assumptions, the female membership premium slightly reduces and becomes flatter at all times; and for males and females, the coverage premium (which remains stronger at the bottom) weakens particularly around the introduction of the NMW (1997 onwards). These two together mean that the total union wage premium reduces compared to raw differentials.

Under endogenous assumptions, the public sector membership premium is reduced to insignificance - an impact that is particularly marked among females. Consequently, as for the private sector, we conclude that there is positive selection into union membership. Overall, the public sector male total union premium is stronger at the bottom of the distribution although significant only in 1991 and 2003; whilst the female total union wage premium remains symmetric across workers and substantial over the whole sample period.

In the public sector, the lack of membership premium combined with a significant coverage premium means that there is a free rider problem. The fact that public sector unions are able to elicit a wage premium reflects their continued strength and indeed militancy in this sheltered sector.

\section{Conclusion}

Union wage premia are examined using U.K. individual-level data over 1991-2003. Quantile regression techniques are employed to examine and elucidate heterogeneity across workers. The total union premium (difference between covered members and non-covered workers) is further disaggregated into its two key components: the membership premium (difference between union member and non-member, conditional on coverage) and the coverage premium (difference between covered non-members and non-covered workers). 
A progressive methodology is applied. We estimate differentials as follows: first, unconditional; second, assuming membership to be exogenous (conditional on other pay determinants); and third, correcting for endogenous membership.

Unconditional results for the private sector suggest the presence of a positive and significant total union wage gap that declines over time. Furthermore, consistent with previous work, unions seem to have greater scope for raising low-paid workers' wages.

But results change once we control for other pay determinants: the feature that unions have greater scope at the bottom of the distribution is no longer apparent. In fact, the total union wage premium among private sector males (determined uniquely by the membership premium) is symmetric across workers in any given year. The size of this premium is about $9 \%$ at the beginning of the 1990 s, declining around the turn of the century to $6-7 \%$. Among females in the private sector, only in the early years is there some evidence of asymmetry, in the form of a total union premium stronger at the bottom (driven by the coverage premium). By the end of the sample, the female union premium has disappeared.

Interestingly, and in line with Booth and Bryan (2004) and Bryson (2002), correcting for endogeneity (in the form of self-selection into membership) eliminates all total union premia in the private sector. This indicates that individuals positively select into unions: joining a union is in part driven by the same characteristics that lead to higher wages. Previous authors have suggested that it is only through controlling for workplace characteristics that it is possible to correctly correct for endogeneity; we show that it is possible to achieve this using individual-level data.

The public sector contrasts greatly with the private sector. Total union wage differentials are large, positive, significant and stronger at the bottom of the distribution (with some compression - particularly for men - around the time the National Minimum Wage was 
established). Introducing other pay determinants tends to reduce the membership premium and weaken the coverage premium.

Correcting for selection into membership weakens the public sector membership premium further. For men, despite numerically large estimates of coverage premia (particularly at the lower end of the distribution), overall the total union premium is generally insignificant once endogeneity is taken into account. In contrast, unions appear to retain the power to extract a wage premium for women, a differential that remains relatively constant across the distribution and over time, at about $20 \%$. So it is women working in the public sector who have managed to keep the total union wage premium over the decade. Correspondingly, it is public sector females who have experienced the least reduction in both union density and coverage. Therefore, this study is in line with the belief that unionization decline is associated with a reduction in the union wage premium, at least over the 1990s in the United Kingdom.

Having corrected for endogeneity, we find no membership premium anywhere. But a free rider problem only exists in the public sector, as it is only here that there is a coverage premium.

Conclusions to be drawn from the estimating procedure include that in general, controlling for other pay determinants and correcting for endogeneity are both important. This study emphasizes the importance, when estimating union wage premium on wages, of controlling for key individual and workplace observable characteristics (firm size is, as noted by Andrews, Bell and Upward 1998, extremely important). Once this is done, heterogeneity in union differentials - that is particularly apparent among private sector men - disappears. In addition, we find it important to endogenise union membership and to allow selection to differ across workers. This has the impact of eliminating the private sector union wage differential. Finally, we conclude that it is necessary to allow the union wage premium to 
vary over time (particularly when the sample period covers developments likely to affect wages and unionization, such as the introduction of the National Minimum Wage), sector and gender. 


\section{References}

Andrews, M. J., Bell, D. N., and Upward, R. (1998). 'Union coverage differentials: some estimates for Britain using the New Earnings Survey Panel Dataset'. Oxford Bulletin of Economics and Statistics, 60 (1): 47-77.

Andrews, M. J., Stewart, M. B., Swaffield, J. K., and Upward, R. (1998). 'The estimation of union wage differentials and the impact of methodological choices'. Labour Economics, 5 (4): 449-474.

Barth, E., Raaum, O., and Naylor, R. (2000). 'Union wage effects: does membership matter?' Manchester School, 68 (3): 259-275.

Blackaby, D. H., Murphy, P. D., and Sloane, P. J. (1991). 'Union membership, collective bargaining coverage and the trade union mark-up for Britain'. Economics Letters. 36 (2): 203-208.

Blanchflower, D. (1991). 'Fear, unemployment and pay flexibility'. Economic Journal. 101 (406): 483-496.

Blanchflower, D., and Bryson, A. (2004). 'The union wage premium in the U.S. and the U.K'. LSE Centre for Economic Performance Discussion Paper 0612.

Blanchflower, D. and Bryson, A. (2007). 'The wage impact of trade unions in the public and private sectors'. IZA Discussion Paper 3055.

Blunch, N-H. and Verner, D. (2004). 'Asymmetries in the union wage premium in Ghana'. The World Bank Economic Review, 18 (2): 237-252.

Booth, A. L. and Bryan, M. L. (2004). 'The union membership wage-premium puzzle: is there a free rider problem?' Industrial and Labor Relations Review, 57 (3): 402-421.

Booth, A. L., Francesconi, M. and Zoega, G. (2003). 'Unions, work-related training and wages: evidence for British men'. Industrial and Labor Relations Review, 57 (1): 68-91. 
Bryson, A. (2002). 'The union membership wage premium: an analysis using Propensity Score Matching'. LSE Centre for Economic Performance Discussion Paper 0530.

Budd, J. and In-Gang N. (2000). 'The union membership wage premium for employees covered by collective bargaining agreements'. Journal of Labour Economics, 18 (4): 783-807.

Buchinsky, M. (1998a). 'Recent advances in quantile regression models: a practical guideline for empirical research'. Journal of Human Resources, 33 (1): 88-126.

Buchinsky, M. (1998b). 'The dynamics of changes in female wage distribution in the US: a quantile regression approach'. Journal of Applied Econometrics, 13 (1): 1-30.

Buchinsky, M. (2001). 'Quantile regression with sample selection: estimating women's return to education in the US'. Empirical Economics, 26 (1): 87-113.

Chamberlain, G. (1994). 'Quantile regression, censoring, and the structure of wages'. In Christopher Sims, ed., Advances in Econometrics, Proceedings of the Sixth World Congress of the Econometric Society, Vol. 1. New York: Cambridge University Press.

Eren, O. (2007). 'Does unionization pay off? A distributional analysis of the free rider problem'. Unpublished paper, Southern Methodist University.

Forth, J. and Millward, N. (2002). 'Union effects on pay levels in Britain'. Labour Economics, 9 (4): 547-561.

Freeman, R. B. and Medoff, J. L. (1984). What Do Unions Do? New York: Basic Books.

Green, F. (1988). 'The trade union wage gap in Britain: some new estimates'. Economics Letters, 27 (2): 183-187.

Hildreth, A. K. (1999). 'What has happened to the union wage differential in Britain in the 1990s?' Oxford Bulletin of Economics and Statistics, 61 (1): 5-31.

Koenker, R. (2005). Quantile Regression. New York: Cambridge University Press. 
Lanot, G. and Walker, I. (1998). 'The union/non-union wage differential: an application of semi-parametric methods'. Journal of Econometrics, 84 (2): 327-349.

Machin, S. (2000). 'Union decline in Britain'. British Journal of Industrial Relations, 38 (4): $631-45$.

Machin, S. (2004). 'Factors of convergence and divergence in union membership'. British Journal of Industrial Relations, 42 (3): 423-38.

Manquilef, A. A. 2007. 'The impact of the National Minimum Wage on individual unionisation propensities in the UK: reversing the trend'. Unpublished paper, University of Warwick.

O’Leary, N. C., Murphy, P. D., and Blackaby, D. H. (2004). 'Quantile regression estimates of the union wage effect for Great Britain'. The Manchester School, 72 (4): 497-514.

Paull, G. (2003). 'BHPS employment histories: user guide'. U.K. Data Archive.

Reilly, K. T. (1996). 'Does union membership matter? The effect of establishment union density on the union wage differential'. Review of Economics and Statistics, 78 (3): $547-557$.

Robinson, C. (1989). 'Union endogeneity and self-selection'. Journal of Labor Economics, 7 (1): 106-112.

Stewart, M. B. (1983). 'Relative earnings and individual union membership in the United Kingdom'. Economica, 50 (198): 111-125.

Stewart, M. B. (1991). 'Union wage differentials in the face of changes in the economic and legal environment'. Economica, 58 (230): 155-172.

Stewart M. B. (1995). 'Union wage differentials in an era of declining unionization'. Oxford Bulletin of Economics and Statistics, 57 (2): 143-166.

Swaffield, J. K. (2001). 'Does measurement error bias fixed-effects estimates of union wage effect?' Oxford Bulletin of Economics and Statistics, 63 (4): 437-457. 
Taylor, M. F., ed., with Brice, J., Buck, N., and Prentice-Lane, E. (2006). British Household Panel Survey User Manual, Volumes A and B. Colchester: University of Essex. 
Figure 1: Raw wage distributions (kernel) by union status and gender in the Private Sector Males Females

1991



1995

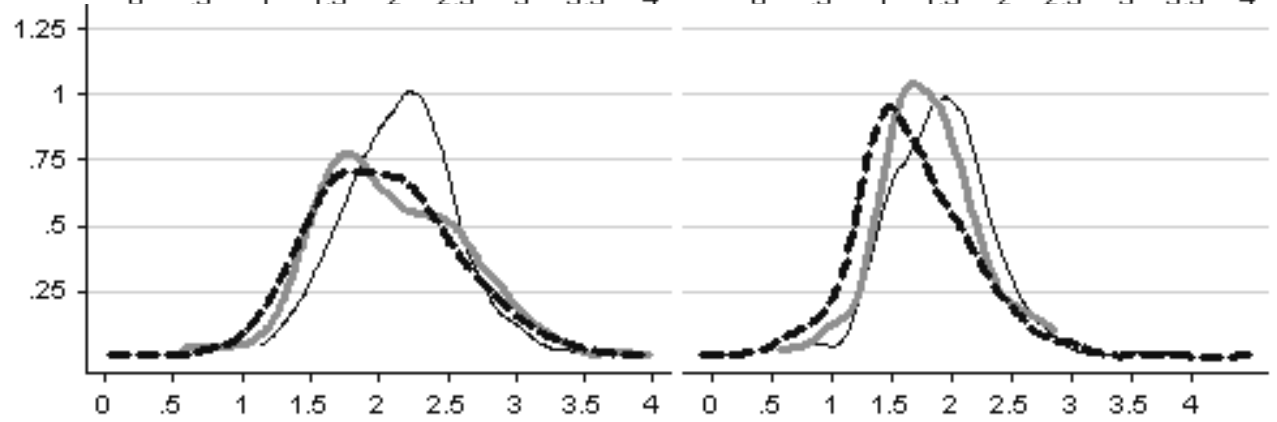

1997
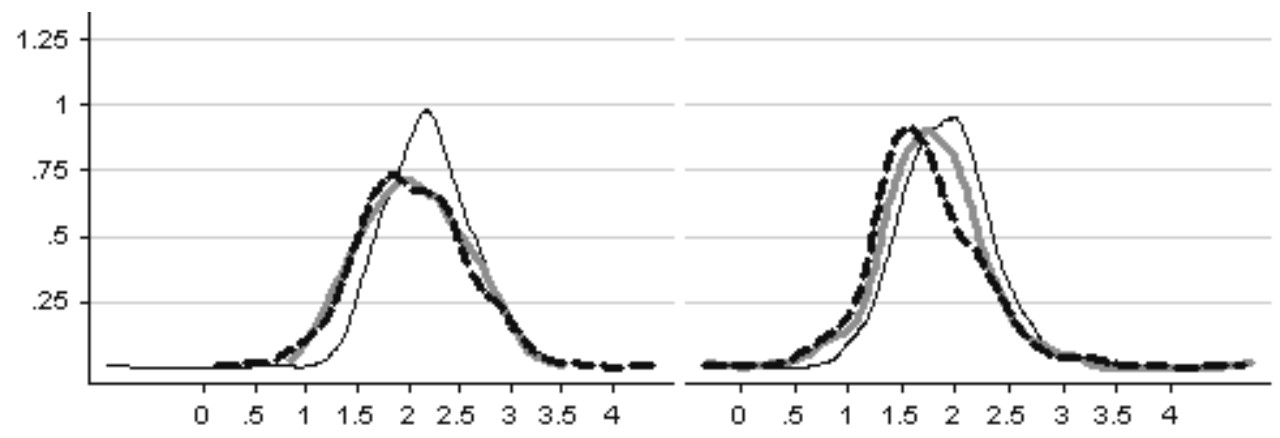

2001


2003

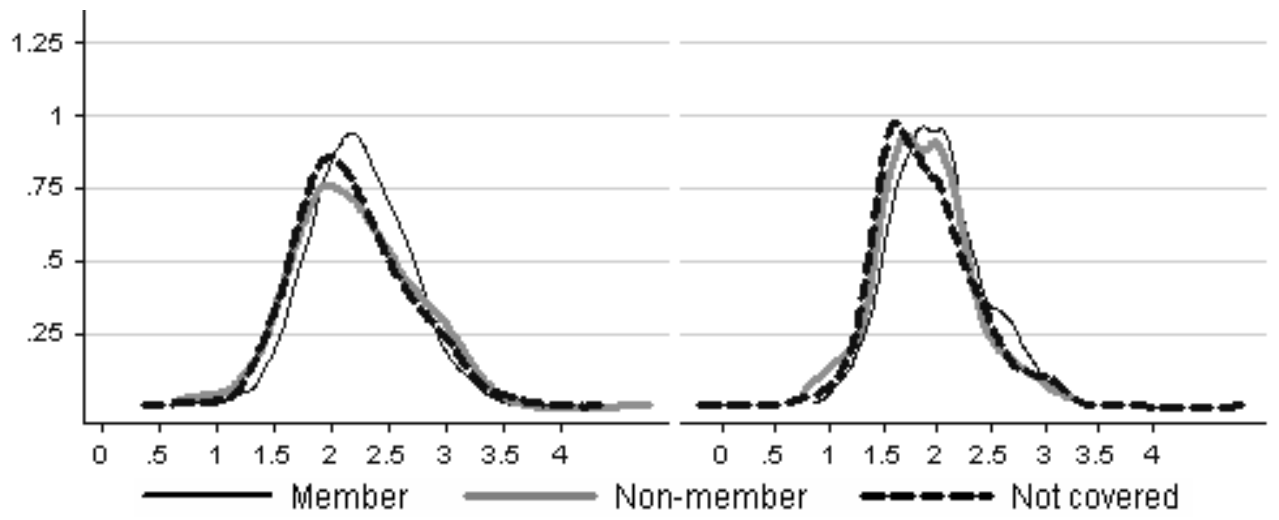


Figure 2: Raw wage distributions (kernel) by union status and gender in the Public Sector

1991 Males Females

1995

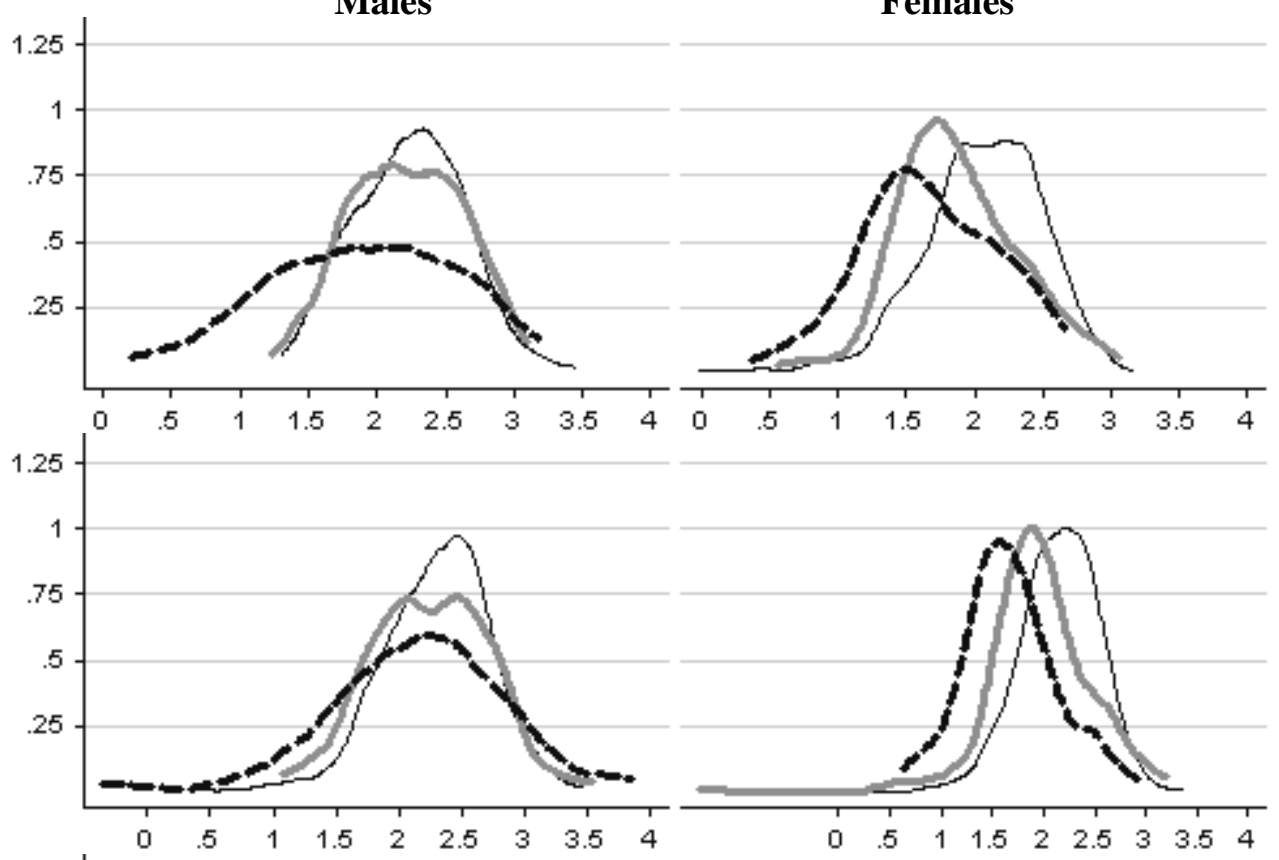

1997

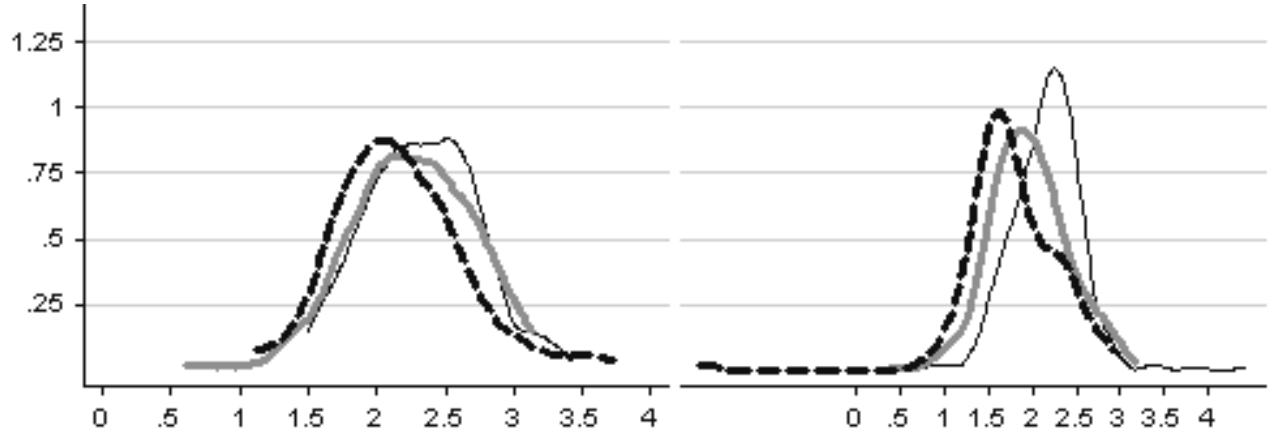

2001

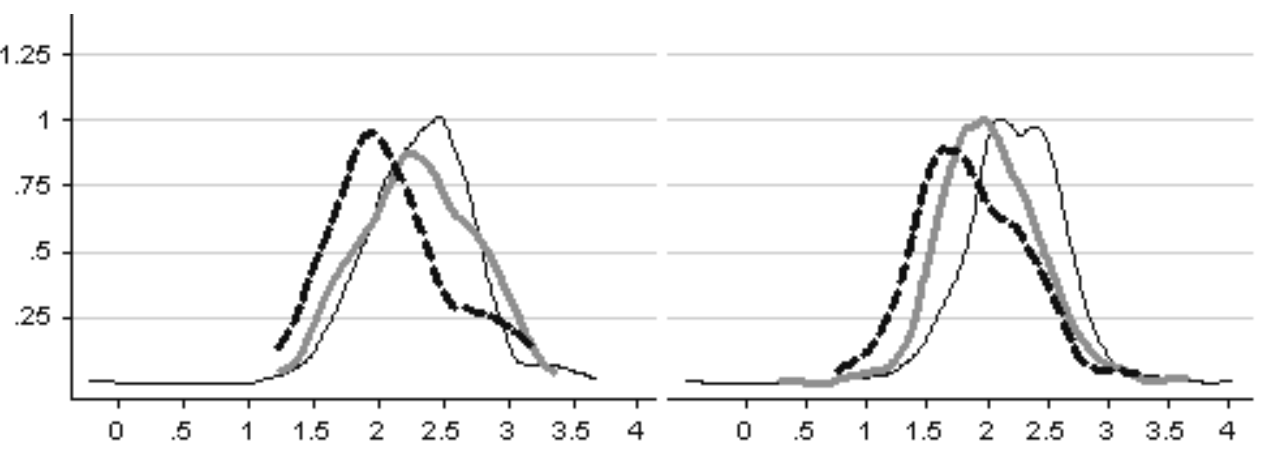

2003

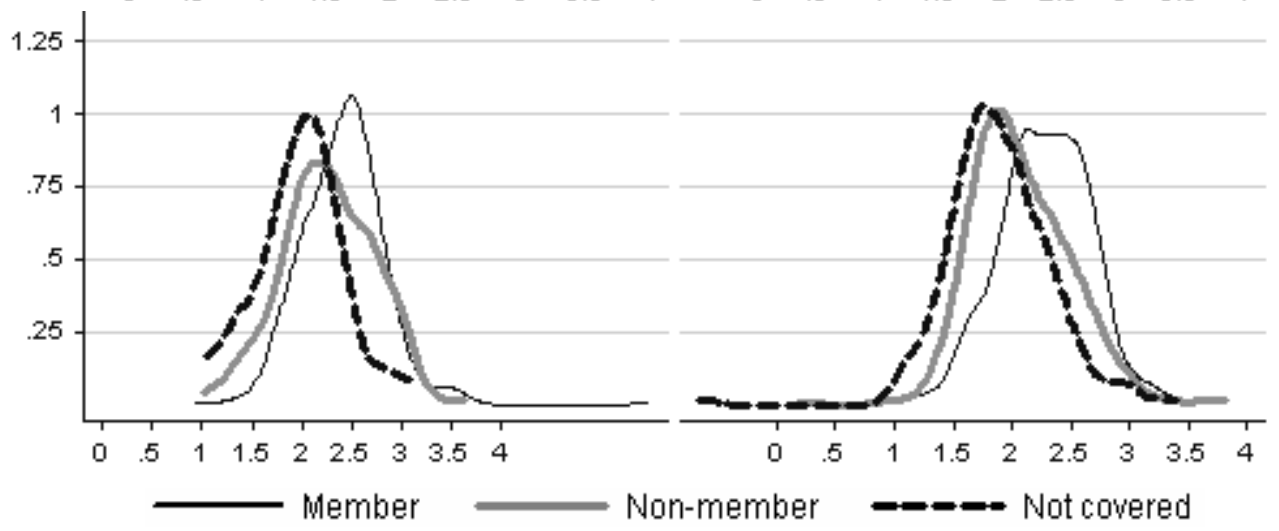




\section{$\underline{\text { Key to Figures 3-8 }}$}

Left-most points give OLS estimates (i.e. estimates at mean); remainder of points show estimates at various deciles $\left(10^{\text {th }}-90^{\text {th }}\right)$.

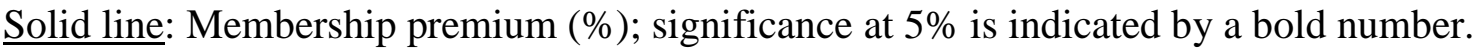

Dashed line: Non-coverage premium (\%); significance at $5 \%$ is indicated by a bold number.

Total premium is given by the distance between these two lines. Significance (at 5\%) of total premium is indicated by a square in the top line.

The base for the membership and non-coverage premia is non-covered non-members. 
Fig 3: Raw membership and non-coverage premia (x100) - Private Sector Males

Females

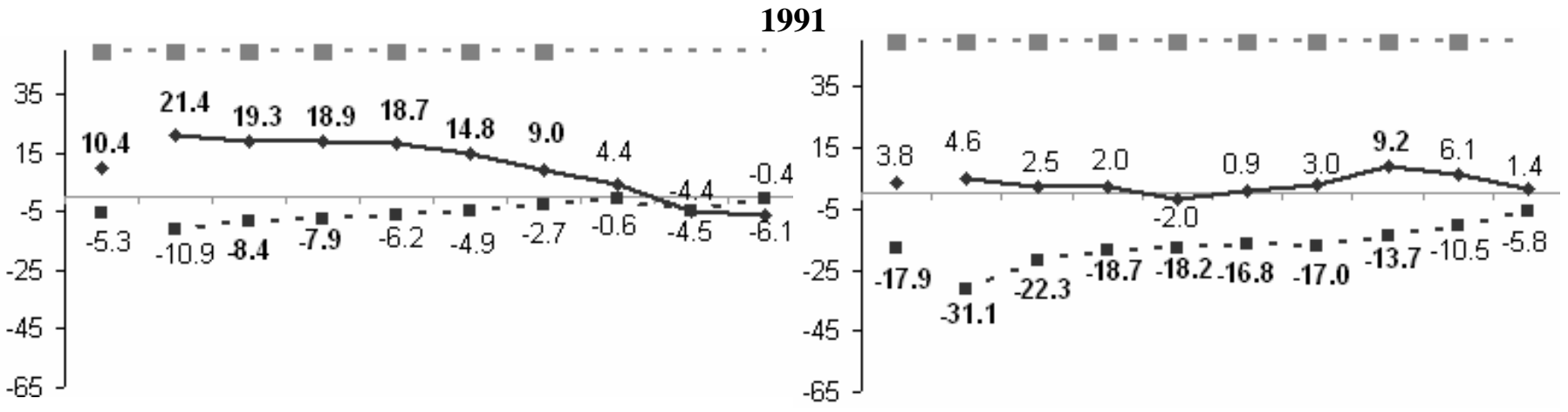

1995

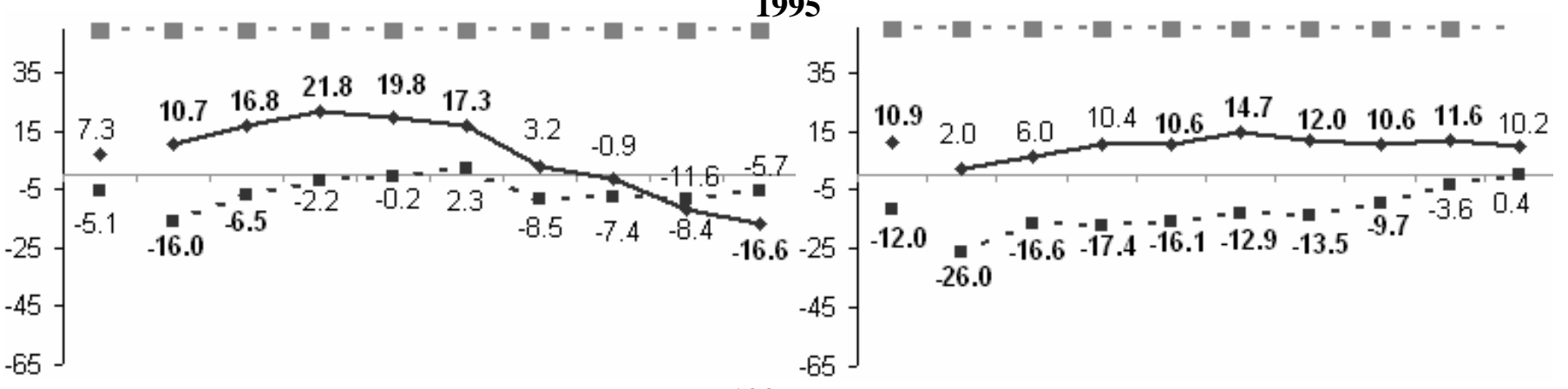

1997



2001

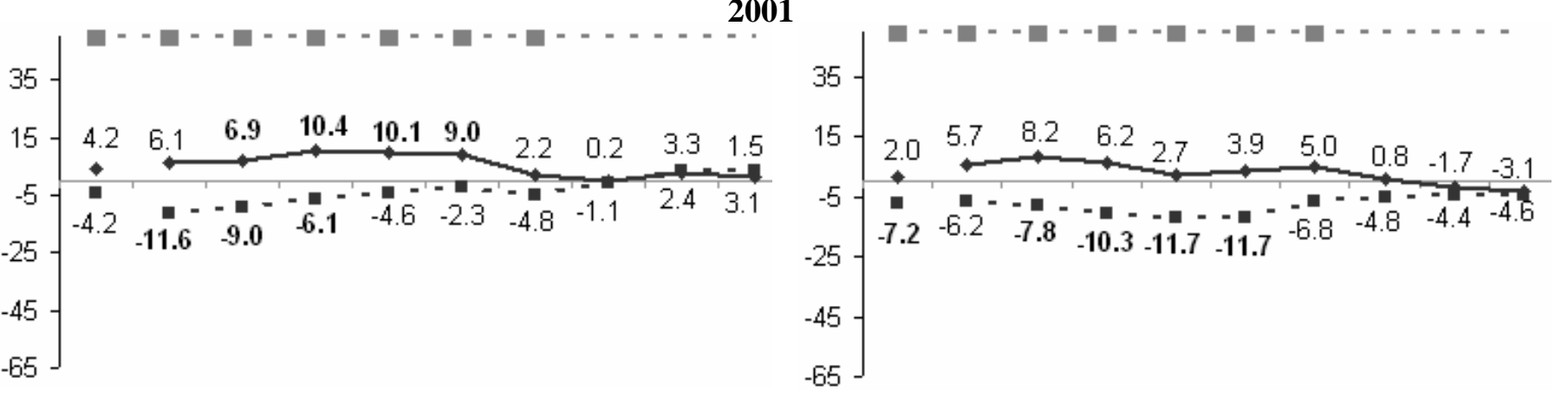

2003

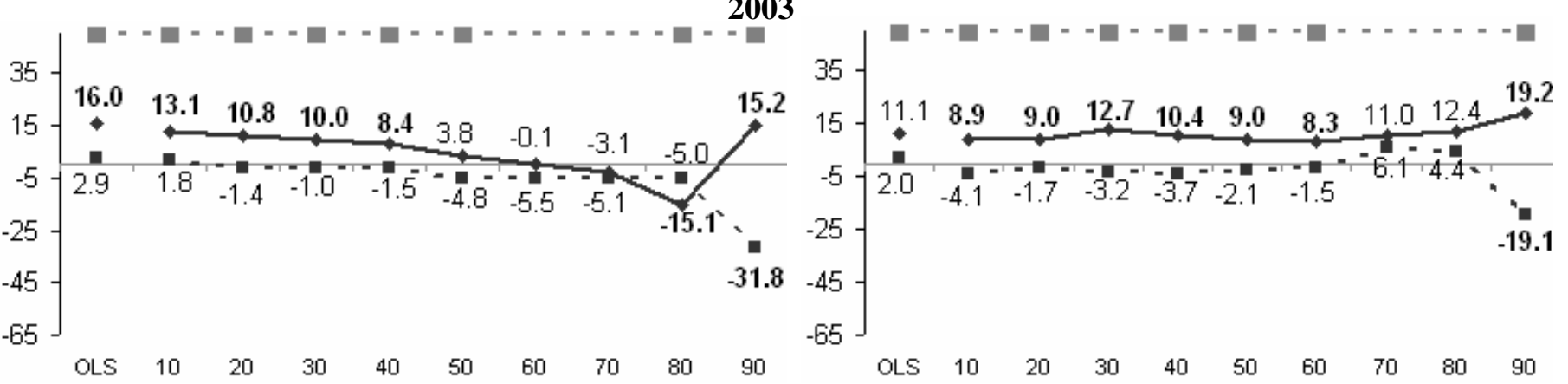


Fig 4: Raw membership and non-coverage premia (x100) - Public Sector Males

1991
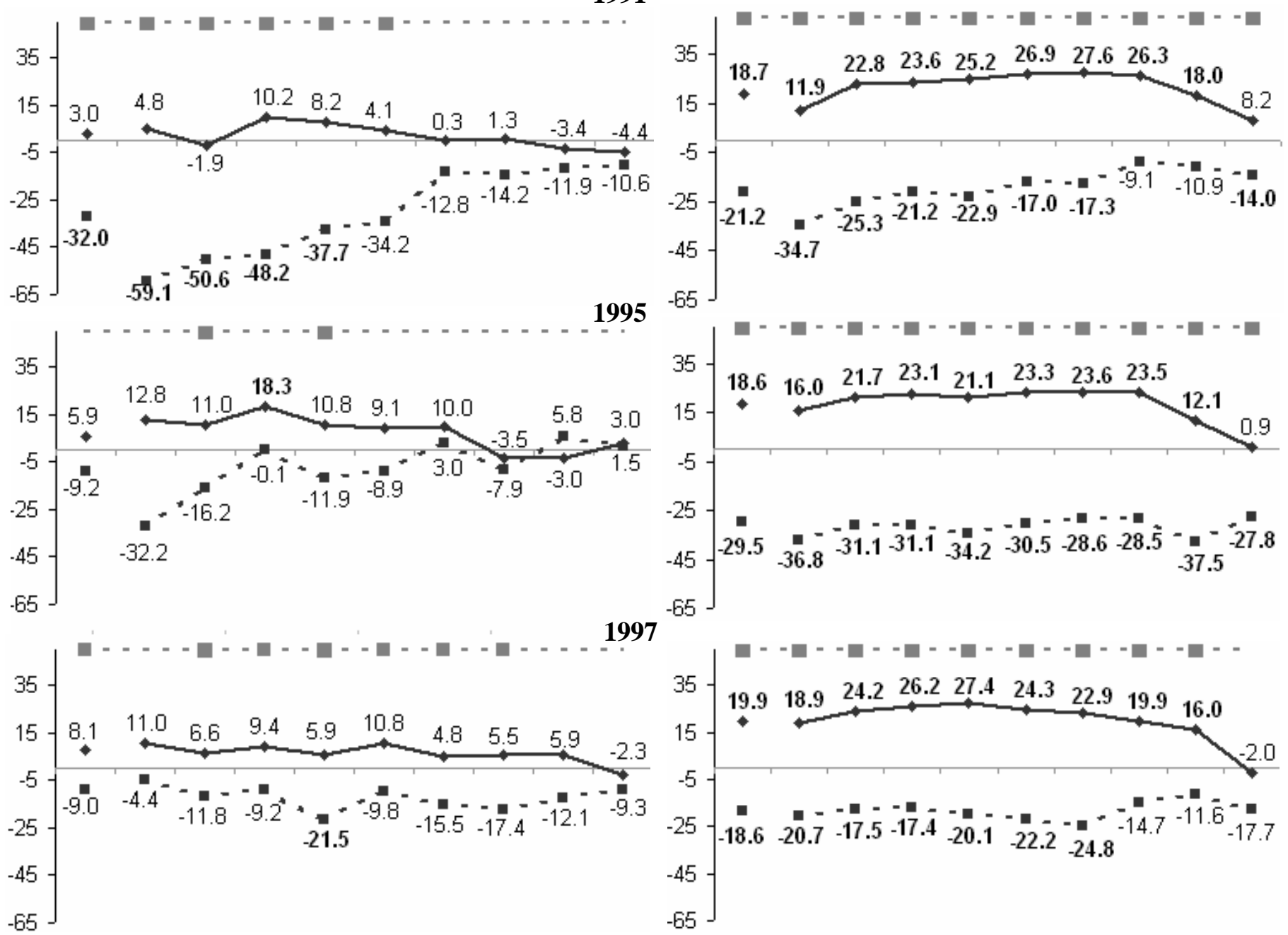

2001
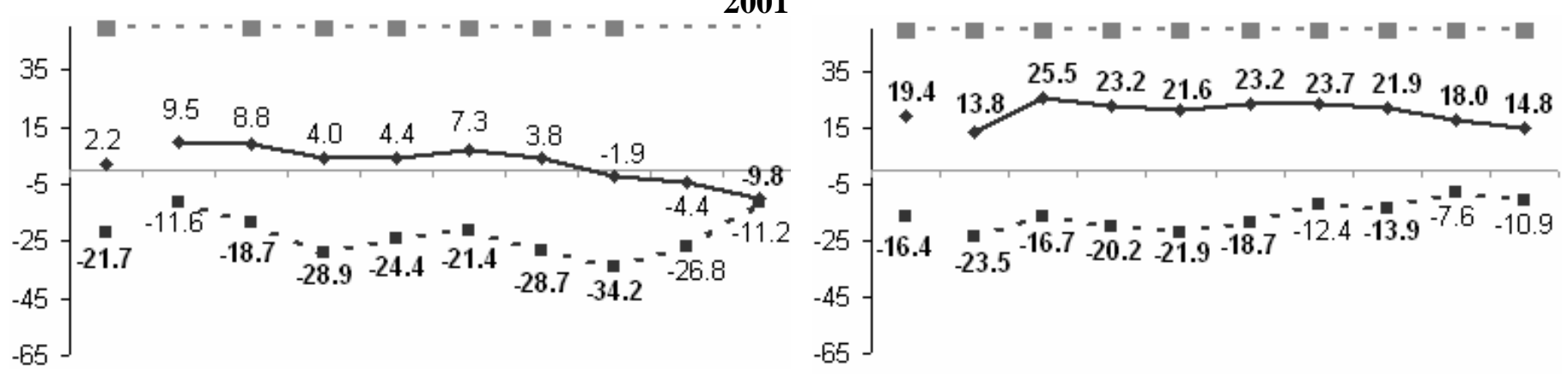

2003
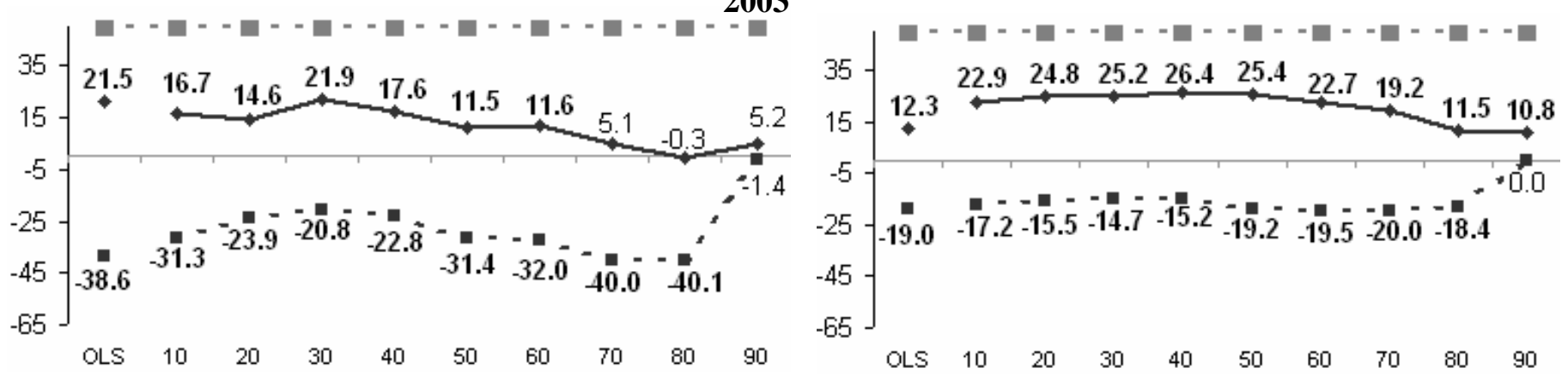
Fig 5: Exogenous membership and non-coverage premia (x100) - Private Sector

\section{Males}

Females

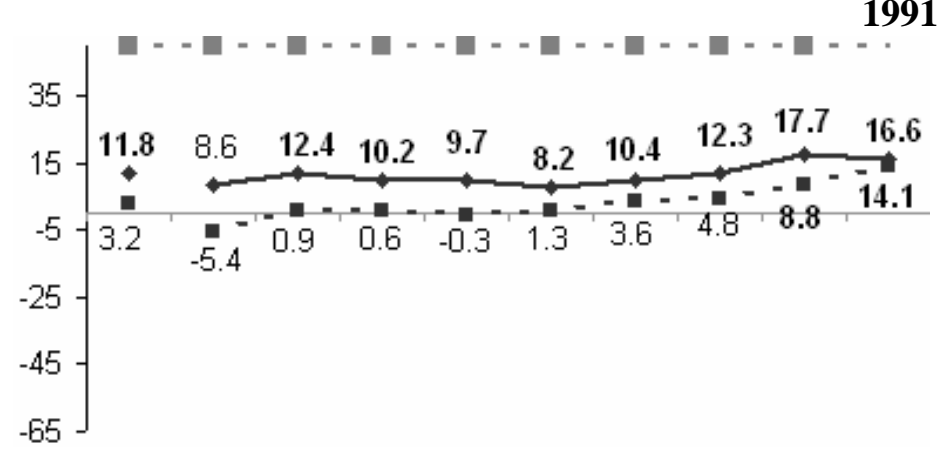

1991

1995
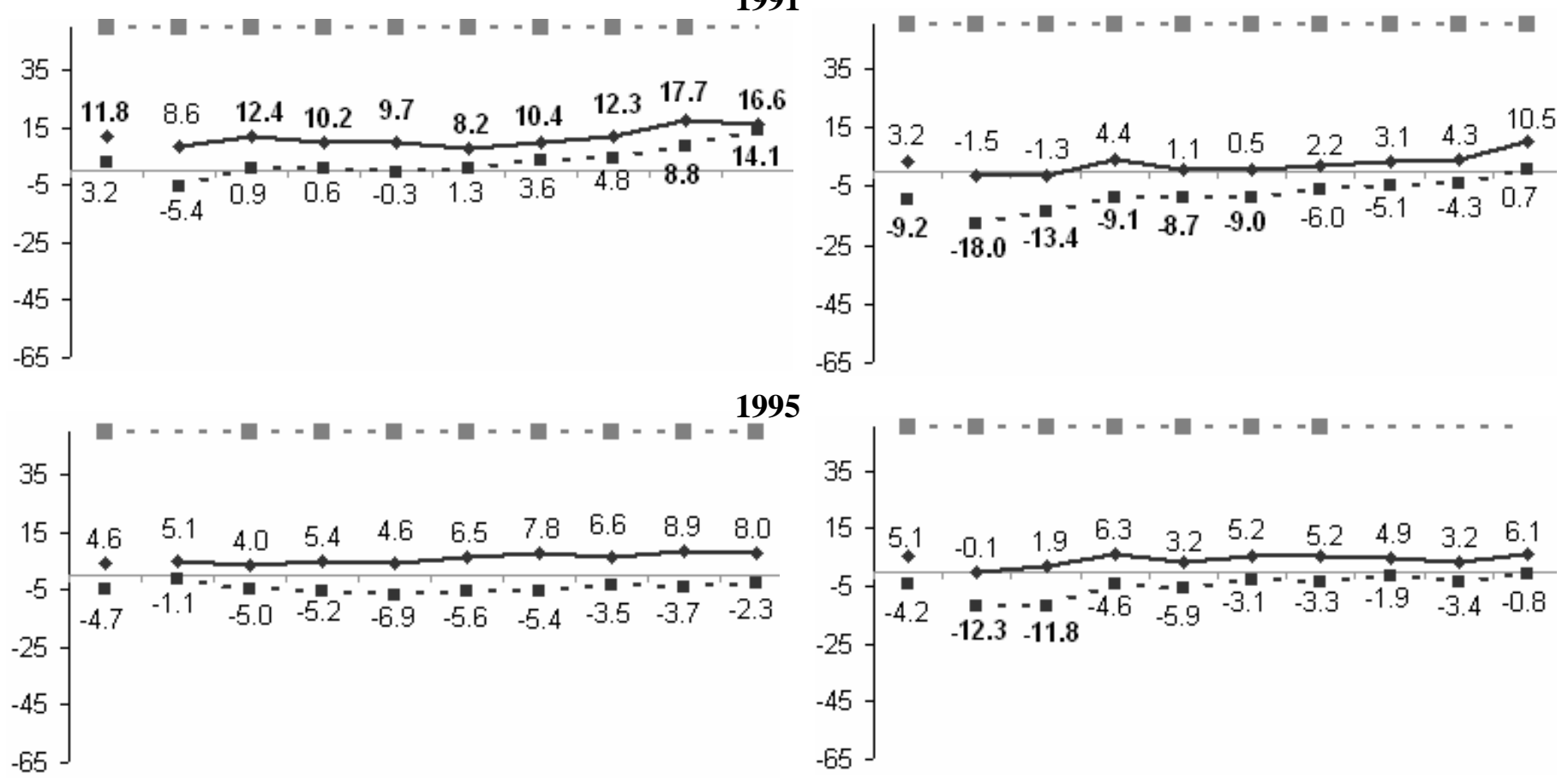

1997
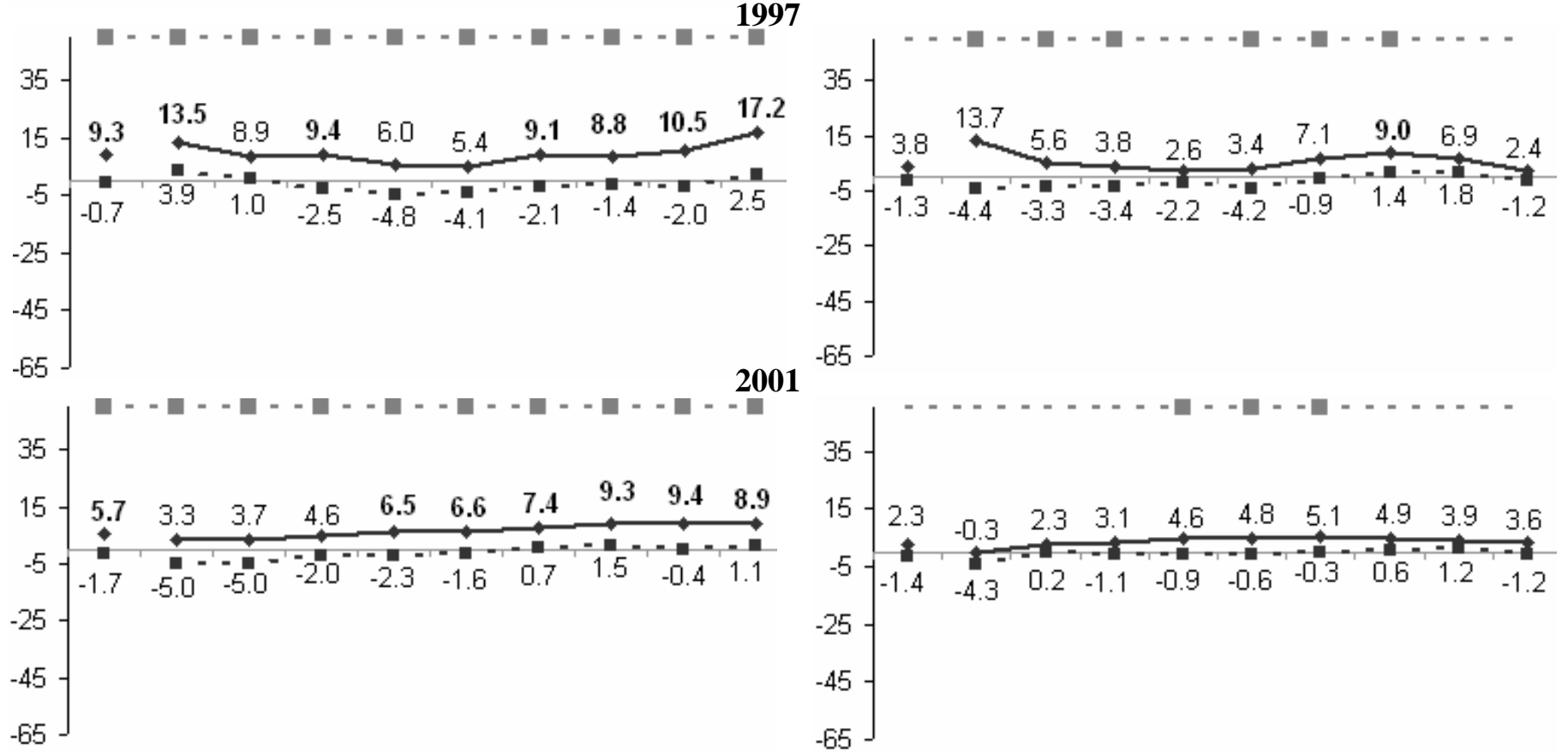

2003


$\frac{\text { Fig 6: Exogenous membership and non-coverage premia (x100) }}{\underline{\text { Males }}}-\frac{\text { Public Sector }}{\underline{\text { Females }}}$

1991
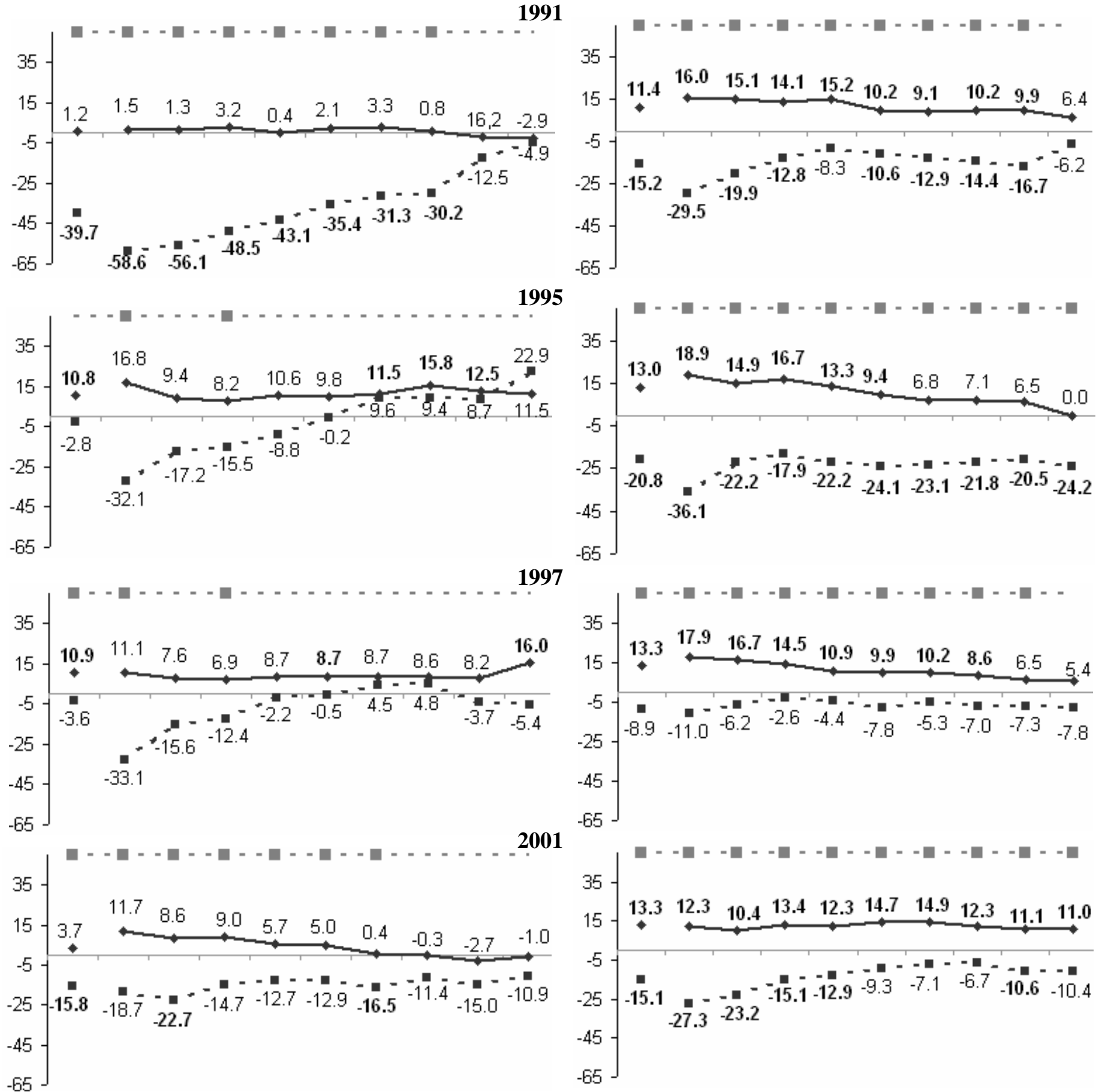

2001
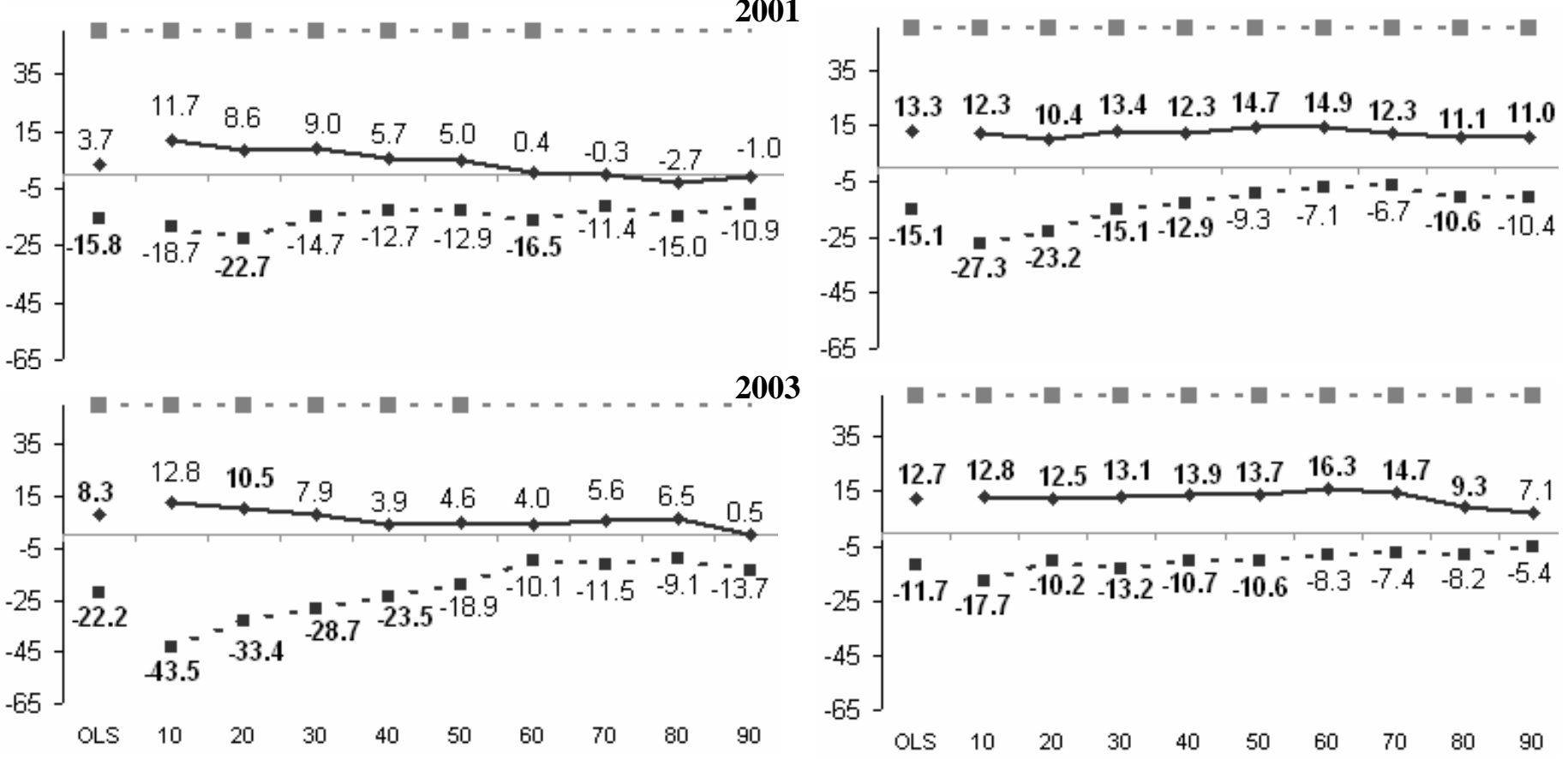
Fig 7: Endogenous membership and non-coverage premia (x100)-Private Sector Males Females

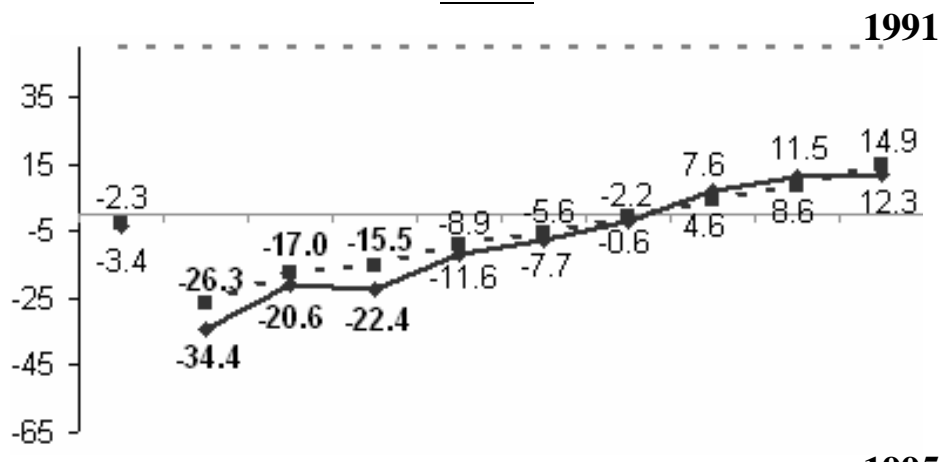

1991

1995
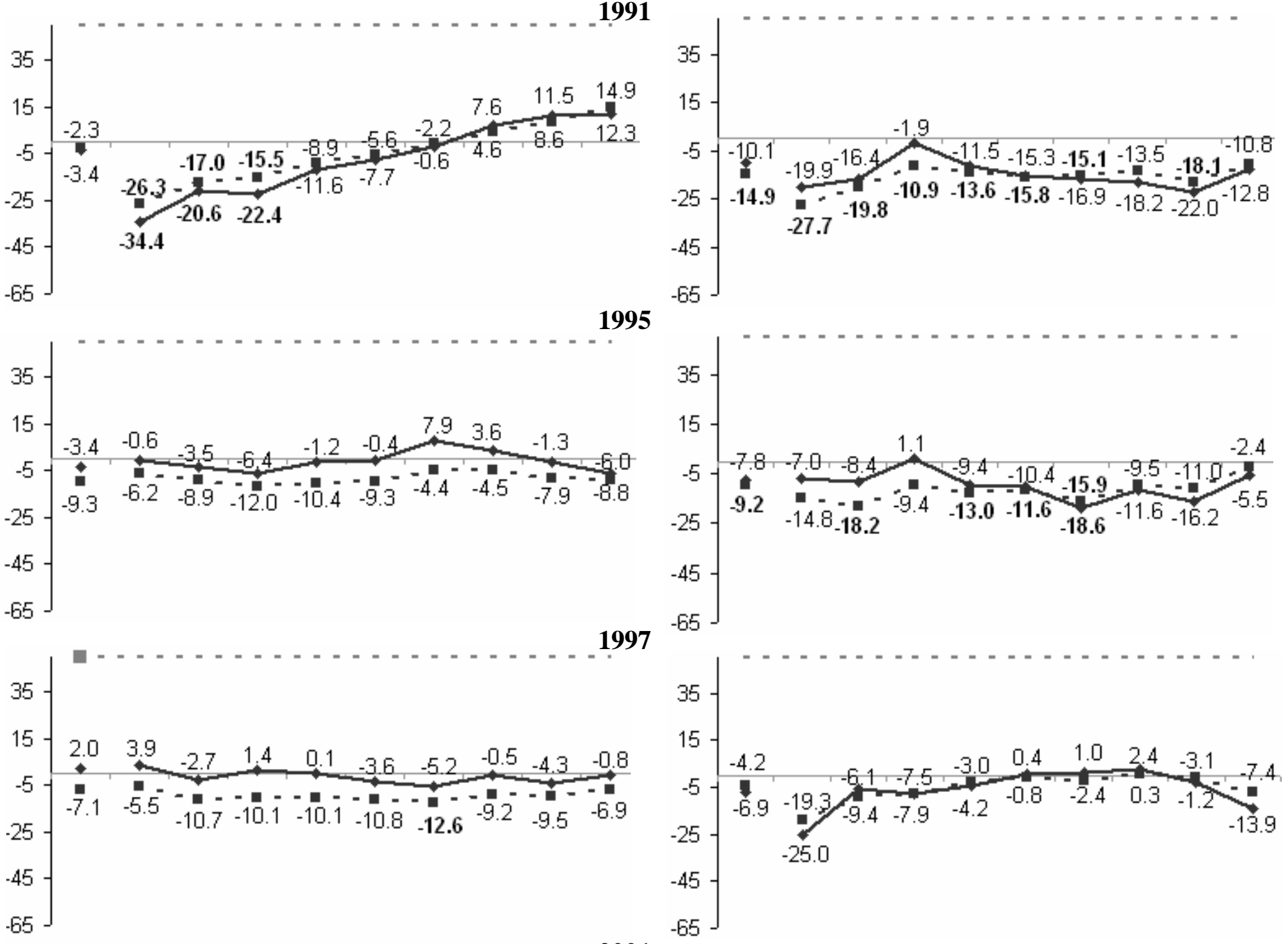

2001

Fig 8: Endogenous membership and non-coverage premia (x100) - Public Sector Males

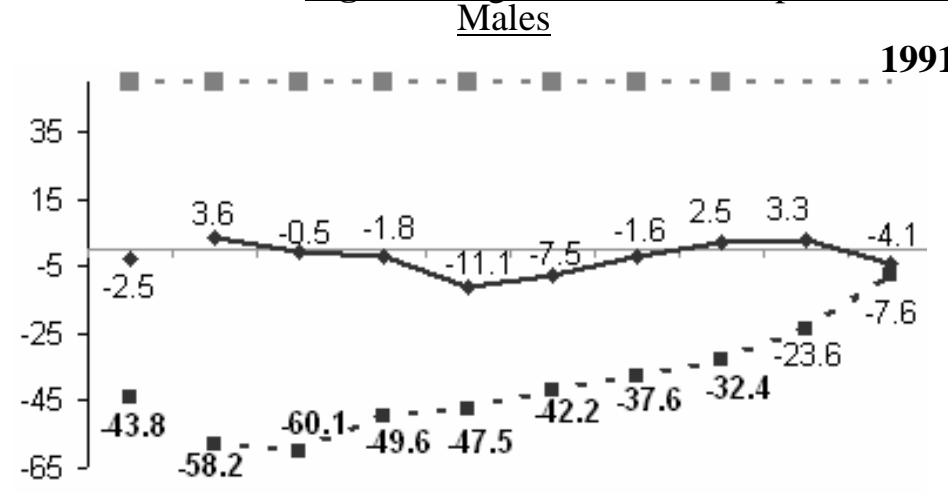

Females

1995
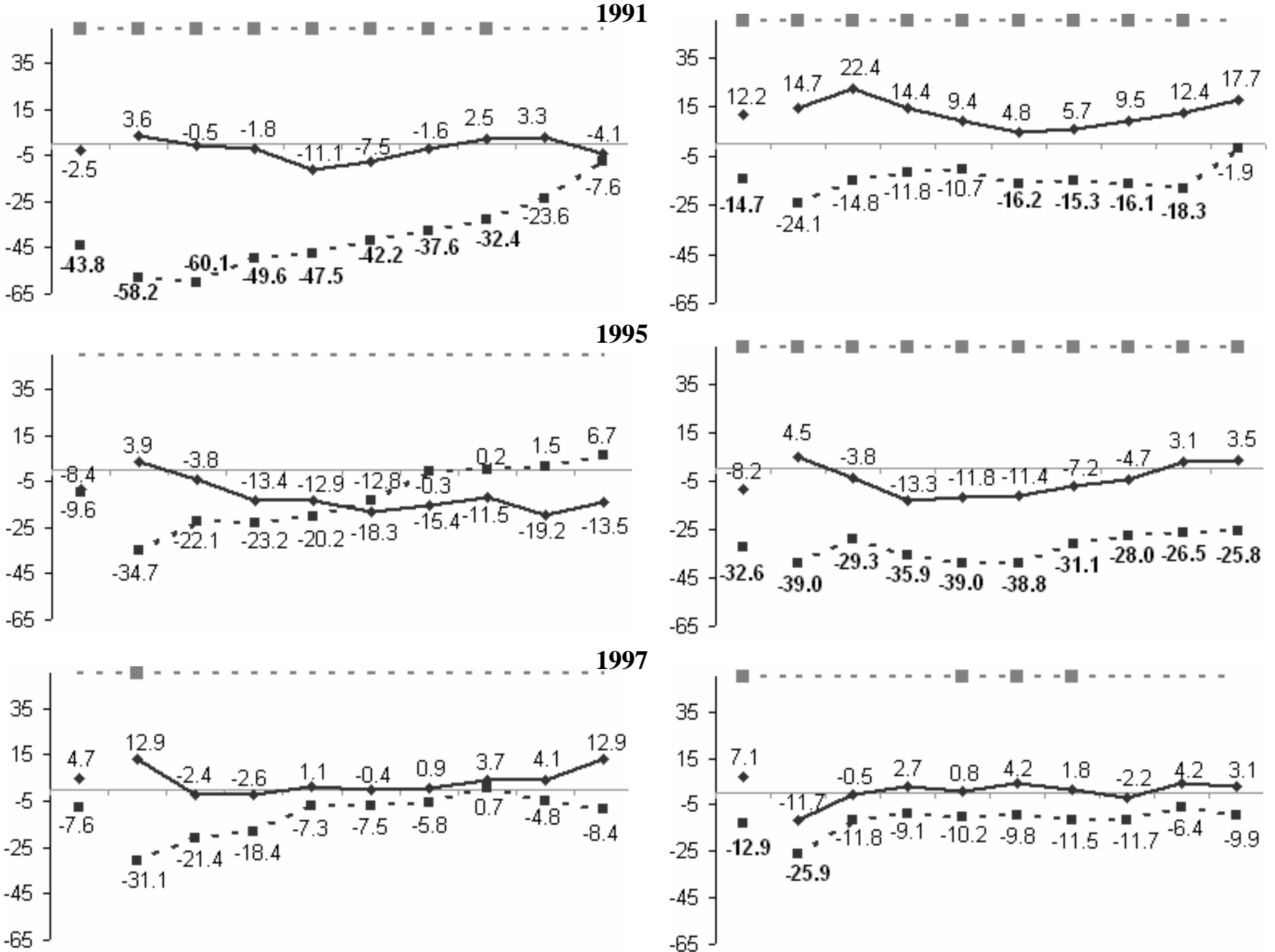

1997

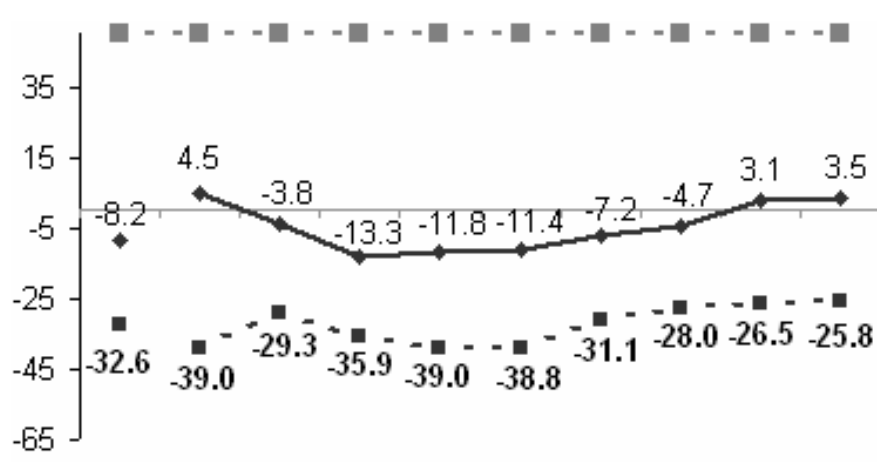

2001
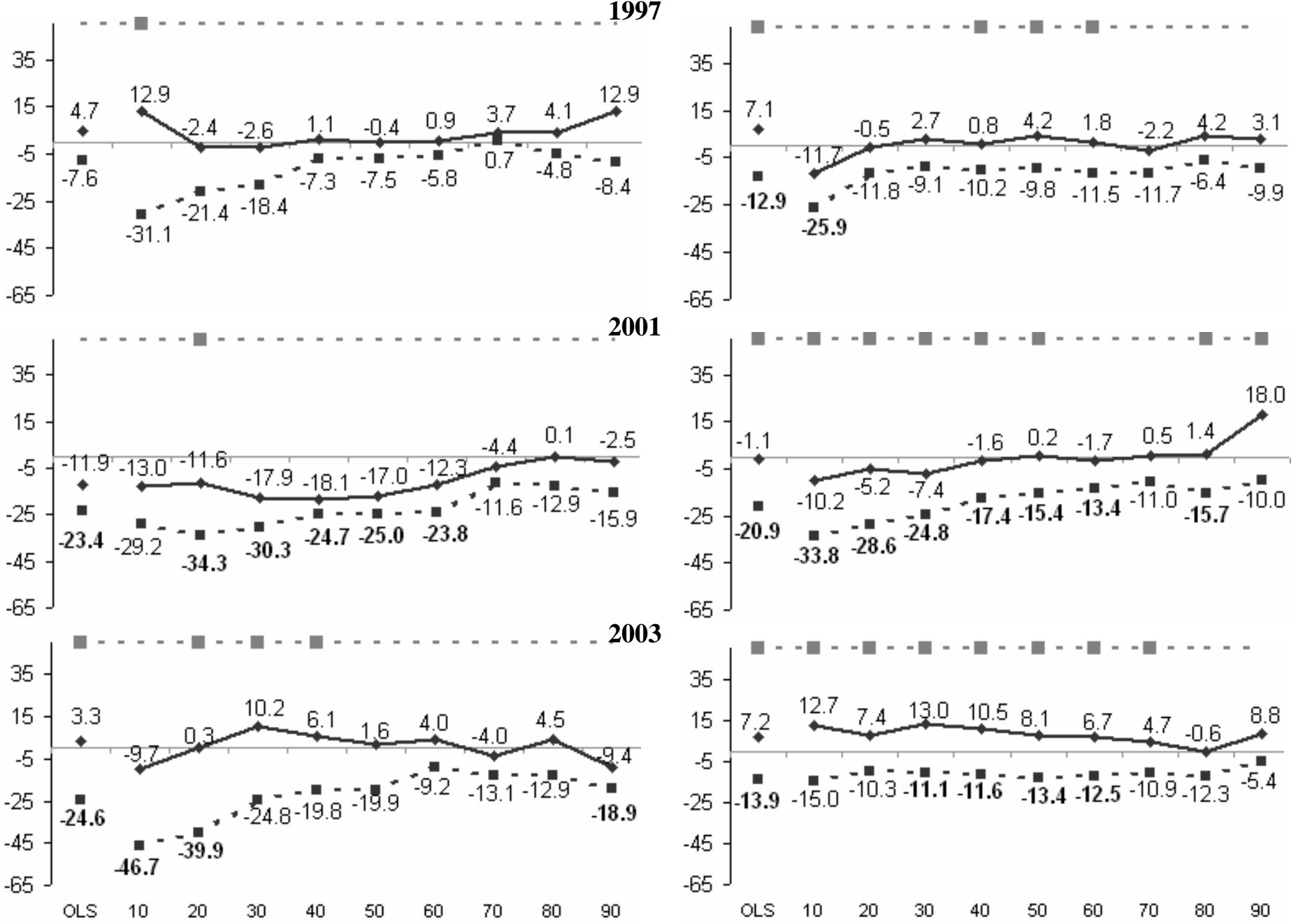
APPENDIX: Table A1: Summary statistics - Mean (Standard deviation)

All

\begin{tabular}{|c|c|c|c|c|c|c|}
\hline \multirow[t]{2}{*}{ Variable } & \multicolumn{3}{|c|}{1991} & \multicolumn{3}{|c|}{2003} \\
\hline & $\begin{array}{c}\text { Union } \\
\text { Member }\end{array}$ & $\begin{array}{c}\text { Non- } \\
\text { member }\end{array}$ & $\begin{array}{c}\text { Not } \\
\text { covered }\end{array}$ & $\begin{array}{c}\text { Union } \\
\text { Member }\end{array}$ & $\begin{array}{c}\text { Non- } \\
\text { member }\end{array}$ & Not covered \\
\hline Ln (hourly wage) & $\begin{array}{c}2.09 \\
(0.42)\end{array}$ & $\begin{array}{c}1.95 \\
(0.46)\end{array}$ & $\begin{array}{c}1.79 \\
(0.57)\end{array}$ & $\begin{array}{c}2.26 \\
(0.43)\end{array}$ & $\begin{array}{c}2.10 \\
(0.49)\end{array}$ & $\begin{array}{c}2.03 \\
(0.51)\end{array}$ \\
\hline Private & 0.48 & 0.53 & 0.92 & 0.37 & 0.53 & 0.90 \\
\hline Woman & 0.46 & 0.57 & 0.53 & 0.56 & 0.55 & 0.49 \\
\hline \multicolumn{7}{|l|}{ Individual information } \\
\hline Tenure (months) & $\begin{array}{c}88.64 \\
(99.39)\end{array}$ & $\begin{array}{c}55.31 \\
(71.19)\end{array}$ & $\begin{array}{c}52.74 \\
(71.10)\end{array}$ & $\begin{array}{c}46.70 \\
(78.40)\end{array}$ & $\begin{array}{c}30.69 \\
(53.27)\end{array}$ & $\begin{array}{c}30.36 \\
(50.72)\end{array}$ \\
\hline Missing tenure & 0.24 & 0.17 & 0.18 & 0.37 & 0.23 & 0.23 \\
\hline Experience (months) & $\begin{array}{c}170.99 \\
(148.79)\end{array}$ & $\begin{array}{c}156.15 \\
(137.63)\end{array}$ & $\begin{array}{c}144.76 \\
(138.30)\end{array}$ & $\begin{array}{c}94.34 \\
(144.25)\end{array}$ & $\begin{array}{c}81.70 \\
(129.81)\end{array}$ & $\begin{array}{c}81.78 \\
(130.29)\end{array}$ \\
\hline Missing experience & 0.25 & 0.20 & 0.22 & 0.59 & 0.54 & 0.55 \\
\hline Training & 0.47 & 042 & 0.30 & 0.33 & 0.30 & 0.21 \\
\hline Married & 0.78 & 0.70 & 0.69 & 0.77 & 0.70 & 0.71 \\
\hline White & 0.96 & 0.97 & 0.97 & 0.95 & 0.93 & 0.95 \\
\hline Health limits work & 0.06 & 0.07 & 0.08 & 0.07 & 0.07 & 0.08 \\
\hline \multicolumn{7}{|l|}{ Qualification } \\
\hline Higher degree & 0.13 & 0.12 & 0.09 & 0.25 & 0.21 & 0.15 \\
\hline Other higher qualification & 0.25 & 0.21 & 0.16 & 0.38 & 0.35 & 0.34 \\
\hline 'A'Level & 0.12 & 0.13 & 0.12 & 0.11 & 0.14 & 0.14 \\
\hline 'O'Level & 0.21 & 0.28 & 0.29 & 0.15 & 0.17 & 0.20 \\
\hline Other qualification & 0.07 & 0.07 & 0.10 & 0.04 & 0.05 & 0.07 \\
\hline Apprentice & 0.02 & 0.02 & 0.01 & 0.00 & 0.01 & 0.01 \\
\hline No qualification at all & 0.20 & 0.18 & 0.22 & 0.06 & 0.07 & 0.10 \\
\hline \multicolumn{7}{|l|}{ Age } \\
\hline$<=25$ & 0.10 & 0.16 & 0.22 & 0.07 & 0.16 & 0.15 \\
\hline $25<=35$ & 0.30 & 0.29 & 0.30 & 0.22 & 0.26 & 0.27 \\
\hline $35<=45$ & 0.30 & 0.29 & 0.24 & 0.34 & 0.30 & 0.29 \\
\hline $0.29>45$ & 0.30 & 0.26 & 0.24 & 0.38 & 0.28 & 0.28 \\
\hline \multicolumn{7}{|l|}{ Residential location } \\
\hline London & 0.09 & 0.14 & 0.11 & 0.05 & 0.07 & 0.06 \\
\hline South East & 0.14 & 0.20 & 0.22 & 0.10 & 0.15 & 0.17 \\
\hline South West & 0.07 & 0.08 & 0.09 & 0.05 & 0.06 & 0.07 \\
\hline East Anglia & 0.02 & 0.04 & 0.05 & 0.02 & 0.02 & 0.03 \\
\hline East Midlands & 0.07 & 0.07 & 0.08 & 0.05 & 0.07 & 0.07 \\
\hline West Midlands & 0.11 & 0.08 & 0.10 & 0.06 & 0.05 & 0.06 \\
\hline North West & 0.12 & 0.09 & 0.10 & 0.09 & 0.07 & 0.08 \\
\hline Yorkshire and Humberside & 0.11 & 0.10 & 0.09 & 0.07 & 0.07 & 0.06 \\
\hline North & 0.10 & 0.05 & 0.05 & 0.06 & 0.04 & 0.04 \\
\hline Wales & 0.06 & 0.04 & 0.04 & 0.21 & 0.16 & 0.16 \\
\hline Scotland & 0.10 & 0.10 & 0.09 & 0.24 & 0.24 & 0.21 \\
\hline $\begin{array}{l}\text { Travel-to-work-area } \\
\text { Unemployment rate }\end{array}$ & $\begin{array}{c}0.08 \\
(0.02) \\
\end{array}$ & $\begin{array}{c}0.08 \\
(0.02) \\
\end{array}$ & $\begin{array}{c}0.08 \\
(0.02) \\
\end{array}$ & $\begin{array}{c}0.03 \\
(0.01) \\
\end{array}$ & $\begin{array}{c}0.03 \\
(0.01) \\
\end{array}$ & $\begin{array}{c}0.02 \\
(0.02) \\
\end{array}$ \\
\hline \multicolumn{7}{|l|}{ Employment characteristics } \\
\hline Permanent contract & 0.96 & 0.89 & 0.94 & 0.98 & 0.95 & 0.97 \\
\hline Full time contract & 0.89 & 0.74 & 0.78 & 0.84 & 0.78 & 0.81 \\
\hline Firm size: $1-24$ employees & 0.17 & 0.25 & 0.48 & 0.20 & 0.21 & 0.47 \\
\hline Firm size: $25-49$ employees & 0.12 & 0.11 & 0.15 & 0.13 & 0.12 & 0.15 \\
\hline Firm size: 50-99 employees & 0.13 & 0.12 & 0.11 & 0.15 & 0.10 & 0.12 \\
\hline Firm size: $>100$ employees & 0.58 & 0.52 & 0.27 & 0.53 & 0.58 & 0.26 \\
\hline Occupation: prof \& manager & 0.17 & 0.18 & 0.22 & 0.22 & 0.22 & 0.29 \\
\hline Occupation: other non manual & 0.45 & 0.58 & 0.46 & 0.51 & 0.54 & 0.42 \\
\hline Occupation: skilled manual & 0.22 & 0.12 & 0.18 & 0.14 & 0.12 & 0.17 \\
\hline $\begin{array}{r}\text { Occupation: semi-skilled man \& } \\
\text { unskilled }\end{array}$ & 0.16 & 0.12 & 0.13 & 0.12 & 0.12 & 0.13 \\
\hline
\end{tabular}


Table A1: Continued - All

\begin{tabular}{|c|c|c|c|c|c|c|}
\hline \multirow[t]{2}{*}{ Variable } & \multicolumn{3}{|c|}{1991} & \multicolumn{3}{|c|}{2003} \\
\hline & $\begin{array}{c}\text { Union } \\
\text { Member }\end{array}$ & Non-member & $\begin{array}{c}\text { Not } \\
\text { covered }\end{array}$ & $\begin{array}{c}\text { Union } \\
\text { Member }\end{array}$ & $\begin{array}{c}\text { Non- } \\
\text { member }\end{array}$ & $\begin{array}{c}\text { Not } \\
\text { covered }\end{array}$ \\
\hline \multicolumn{7}{|l|}{ Employment characteristics } \\
\hline Industry: energy and water & 0.05 & 0.02 & 0.01 & 0.02 & 0.02 & 0.01 \\
\hline Industry: chemical & 0.04 & 0.03 & 0.03 & 0.02 & 0.01 & 0.02 \\
\hline Industry: engineering & 0.09 & 0.10 & 0.13 & 0.05 & 0.06 & 0.09 \\
\hline Industry: other manufacture & 0.09 & 0.10 & 0.13 & 0.06 & 0.07 & 0.09 \\
\hline Industry: construction & 0.02 & 0.03 & 0.04 & 0.02 & 0.03 & 0.06 \\
\hline Industry: distribution & 0.05 & 0.12 & 0.29 & 0.07 & 0.14 & 0.28 \\
\hline Industry: transport & 0.10 & 0.04 & 0.03 & 0.03 & 0.02 & 0.02 \\
\hline Industry: banking & 0.09 & 0.11 & 0.15 & 0.06 & 0.09 & 0.09 \\
\hline Industry: other services & 0.46 & 0.45 & 0.17 & 0.67 & 0.55 & 0.35 \\
\hline \multicolumn{7}{|l|}{ INSTRUMENTS } \\
\hline Party supporter & $\overline{0.44}$ & 0.39 & $\overline{c 0.36}$ & 0.34 & $\overline{c 0.28}$ & $\overline{c 0.26}$ \\
\hline \multicolumn{7}{|l|}{ Type of school attended } \\
\hline Comprehensive & 0.70 & 0.68 & 0.73 & 0.76 & 0.74 & 0.77 \\
\hline Grammar no fee & 0.17 & 0.17 & 0.13 & 0.11 & 0.10 & 0.09 \\
\hline Private school & 0.05 & 0.07 & 0.07 & 0.04 & 0.05 & 0.05 \\
\hline Technical school & 0.08 & 0.08 & 0.08 & 0.09 & 0.10 & 0.09 \\
\hline \multicolumn{7}{|l|}{ Household Information } \\
\hline House is owned & 0.82 & 0.81 & 0.75 & 0.86 & 0.80 & 0.77 \\
\hline House: City Council & 0.12 & 0.12 & 0.14 & 0.08 & 0.10 & 0.12 \\
\hline House is rented & 0.06 & 0.07 & 0.11 & 0.06 & 0.10 & 0.12 \\
\hline There is a child between 0 and 2 & 0.08 & 0.06 & 0.08 & 0.06 & 0.07 & 0.07 \\
\hline There is a child between 3 and 4 & 0.08 & 0.08 & 0.08 & 0.08 & 0.09 & 0.08 \\
\hline There is a child between 5 and 11 & 0.20 & 0.20 & 0.21 & 0.24 & 0.23 & 0.22 \\
\hline There is a child between 12 and 15 & 0.16 & 0.15 & 0.17 & 0.18 & 0.17 & 0.16 \\
\hline There is a child between 16 and 18 & 0.06 & 0.07 & 0.07 & 0.05 & 0.05 & 0.04 \\
\hline Partner employed & 0.65 & 0.59 & 0.57 & 0.67 & 0.60 & 0.60 \\
\hline \multicolumn{7}{|l|}{ Parental Background } \\
\hline Father: missing values & 0.10 & 0.10 & 0.10 & 0.16 & 0.25 & 0.26 \\
\hline Father: professional non manиal & 0.30 & 0.36 & 0.33 & 0.32 & 0.30 & 0.29 \\
\hline Father: skilled manual & 0.36 & 0.33 & 0.33 & 0.30 & 0.26 & 0.26 \\
\hline Father: semi skilled and unskilled & 0.15 & 0.13 & 0.14 & 0.13 & 0.10 & 0.10 \\
\hline Father: own occupation and other & 0.08 & 0.09 & 0.11 & 0.09 & 0.10 & 0.09 \\
\hline Mother: missing values & 0.46 & 0.50 & 0.48 & 0.44 & 0.51 & 0.50 \\
\hline Mother: professional non maпиаl & 0.33 & 0.32 & 0.31 & 0.38 & 0.33 & 0.33 \\
\hline Mother: skilled manual & 0.04 & 0.03 & 0.03 & 0.03 & 0.02 & 0.03 \\
\hline Mother: semi skilled and unskilled & 0.14 & 0.12 & 0.14 & 0.13 & 0.11 & 0.12 \\
\hline Mother: own occupation and other & 0.03 & 0.02 & 0.03 & 0.02 & 0.03 & 0.03 \\
\hline \multicolumn{7}{|l|}{ Employment Information } \\
\hline Work not during business hours & 0.36 & 0.30 & 0.28 & 0.39 & 0.37 & 0.33 \\
\hline Work overtime & 0.50 & 0.38 & 0.44 & 0.49 & 0.45 & 0.46 \\
\hline Want to work fewer hours & 0.35 & 0.26 & 0.30 & 0.37 & 0.29 & 0.36 \\
\hline Works at workplace & 0.82 & 0.86 & 0.84 & 0.82 & 0.85 & 0.81 \\
\hline Remuneration scheme & 0.93 & 0.79 & 0.45 & 0.95 & 0.91 & 0.58 \\
\hline Bonus incentives & 0.31 & 0.30 & 0.28 & 0.23 & 0.24 & 0.36 \\
\hline Promotion opportunities at work & 0.67 & 0.58 & 0.40 & 0.64 & 0.62 & 0.41 \\
\hline Number of Observations & 1,495 & 658 & 1,760 & 1,673 & 1,076 & 2,391 \\
\hline
\end{tabular}




\section{APPENDIX: Table A2: Summary statistics - Mean (Standard deviation) Males in the Private Sector}

\begin{tabular}{|c|c|c|c|c|c|c|}
\hline \multirow[t]{2}{*}{ Variable } & \multicolumn{3}{|c|}{1991} & \multicolumn{3}{|c|}{2003} \\
\hline & $\begin{array}{l}\text { Union } \\
\text { Member }\end{array}$ & $\begin{array}{c}\text { Non- } \\
\text { member }\end{array}$ & $\begin{array}{c}\text { Not } \\
\text { covered }\end{array}$ & $\begin{array}{c}\text { Union } \\
\text { Member }\end{array}$ & $\begin{array}{c}\text { Non- } \\
\text { member }\end{array}$ & Not covered \\
\hline Ln (hourly wage) & $\begin{array}{c}2.14 \\
(0.41)\end{array}$ & $\begin{array}{c}2.04 \\
(0.49) \\
\end{array}$ & $\begin{array}{c}1.99 \\
(0.57)\end{array}$ & $\begin{array}{c}2.24 \\
(0.43)\end{array}$ & $\begin{array}{c}2.20 \\
(0.54)\end{array}$ & $\begin{array}{c}2.18 \\
(0.51)\end{array}$ \\
\hline \multicolumn{7}{|l|}{ Individual information } \\
\hline Tenure (months) & $\begin{array}{c}91.86 \\
(107.96)\end{array}$ & $\begin{array}{c}67.73 \\
(80.68)\end{array}$ & $\begin{array}{c}51.69 \\
(74.88)\end{array}$ & $\begin{array}{c}50.79 \\
(86.78)\end{array}$ & $\begin{array}{c}32.70 \\
(56.76)\end{array}$ & $\begin{array}{c}29.68 \\
(51.92)\end{array}$ \\
\hline Missing tenure & 0.29 & 0.19 & 0.22 & 0.37 & 0.22 & 0.25 \\
\hline Experience (months) & $\begin{array}{c}181.64 \\
(166.06)\end{array}$ & $\begin{array}{c}150.92 \\
(149.34)\end{array}$ & $\begin{array}{c}141.50 \\
(149.27)\end{array}$ & $\begin{array}{c}98.16 \\
(155.51)\end{array}$ & $\begin{array}{c}75.85 \\
(131.50)\end{array}$ & $\begin{array}{c}78.55 \\
(131.59)\end{array}$ \\
\hline Missing experience & 0.31 & 0.23 & 0.27 & 0.61 & 0.57 & 0.57 \\
\hline Training & 0.40 & 0.42 & 0.32 & 0.21 & 0.30 & 0.20 \\
\hline Married & 0.82 & 0.67 & 0.67 & 0.76 & 0.70 & 0.72 \\
\hline White & 0.97 & 0.95 & 0.96 & 0.94 & 0.91 & 0.95 \\
\hline Health limits work & 0.05 & 0.07 & 0.07 & 0.08 & 0.05 & 0.07 \\
\hline \multicolumn{7}{|l|}{ Qualification } \\
\hline Higher degree & 0.04 & 0.13 & 0.12 & 0.09 & 0.17 & 0.18 \\
\hline Other higher qualification & 0.20 & 0.21 & 0.21 & 0.39 & 0.39 & 0.35 \\
\hline 'A'Level & 0.16 & 0.19 & 0.15 & 0.17 & 0.15 & 0.14 \\
\hline 'O'Level & 0.22 & 0.25 & 0.24 & 0.18 & 0.16 & 0.18 \\
\hline Other qualification & 0.08 & 0.04 & 0.07 & 0.06 & 0.05 & 0.05 \\
\hline Apprentice & 0.05 & 0.03 & 0.03 & 0.02 & 0.02 & 0.01 \\
\hline No qualification at all & 0.25 & 0.15 & 0.19 & 0.09 & 0.08 & 0.09 \\
\hline \multicolumn{7}{|l|}{ Age } \\
\hline$<=25$ & 0.09 & 0.22 & 0.24 & 0.11 & 0.21 & 0.16 \\
\hline $25<=35$ & 0.30 & 0.33 & 0.32 & 0.20 & 0.27 & 0.31 \\
\hline $35<=45$ & 0.29 & 0.25 & 0.22 & 0.32 & 0.27 & 0.28 \\
\hline$>45$ & 0.31 & 0.21 & 0.21 & 0.37 & 0.25 & 0.25 \\
\hline \multicolumn{7}{|l|}{ Residential location } \\
\hline London & 0.06 & 0.10 & 0.10 & 0.03 & 0.04 & 0.06 \\
\hline South East & 0.13 & 0.21 & 0.22 & 0.08 & 0.16 & 0.16 \\
\hline South West & 0.09 & 0.09 & 0.08 & 0.07 & 0.06 & 0.08 \\
\hline East Anglia & 0.03 & 0.05 & 0.05 & 0.03 & 0.02 & 0.04 \\
\hline East Midlands & 0.08 & 0.05 & 0.08 & 0.06 & 0.06 & 0.07 \\
\hline West Midlands & 0.12 & 0.07 & 0.10 & 0.05 & 0.06 & 0.06 \\
\hline North West & 0.12 & 0.10 & 0.10 & 0.10 & 0.07 & 0.07 \\
\hline Yorkshire and Humberside & 0.11 & 0.12 & 0.09 & 0.08 & 0.09 & 0.06 \\
\hline North & 0.12 & 0.04 & 0.05 & 0.07 & 0.05 & 0.04 \\
\hline Wales & 0.07 & 0.05 & 0.04 & 0.24 & 0.16 & 0.14 \\
\hline Scotland & 0.06 & 0.13 & 0.09 & 0.17 & 0.24 & 0.21 \\
\hline $\begin{array}{l}\text { Travel-to-work-area } \\
\text { Unemployment rate }\end{array}$ & $\begin{array}{c}0.08 \\
(0.02)\end{array}$ & $\begin{array}{c}0.08 \\
(0.02)\end{array}$ & $\begin{array}{c}0.08 \\
(0.02)\end{array}$ & $\begin{array}{c}0.03 \\
(0.01)\end{array}$ & $\begin{array}{c}0.03 \\
(0.01)\end{array}$ & $\begin{array}{c}0.02 \\
(0.01)\end{array}$ \\
\hline \multicolumn{7}{|l|}{ Employment characteristics } \\
\hline Permanent contract & 0.97 & 0.94 & 0.96 & 0.99 & 0.97 & 0.97 \\
\hline Full time contract & 0.99 & 0.96 & 0.97 & 0.99 & 0.98 & 0.98 \\
\hline Firm size: 1-24 employees & 0.11 & 0.19 & 0.40 & 0.11 & 0.16 & 0.42 \\
\hline Firm size: $25-49$ employees & 0.10 & 0.10 & 0.16 & 0.08 & 0.10 & 0.16 \\
\hline Firm size: 50-99 employees & 0.12 & 0.12 & 0.12 & 0.14 & 0.10 & 0.12 \\
\hline Firm size: $>100$ employees & 0.67 & 0.59 & 0.32 & 0.66 & 0.64 & 0.30 \\
\hline Occupation: prof \& manager & 0.15 & 0.30 & 0.32 & 0.17 & 0.30 & 0.34 \\
\hline Occupation: other non manual & 0.17 & 0.28 & 0.21 & 0.20 & 0.26 & 0.23 \\
\hline Occupation: skilled manual & 0.50 & 0.29 & 0.35 & 0.42 & 0.31 & 0.30 \\
\hline $\begin{array}{r}\text { Occupation: semi-skilled man \& } \\
\text { unskilled }\end{array}$ & 0.19 & 0.14 & 0.12 & 0.21 & 0.13 & 0.13 \\
\hline
\end{tabular}


Table A2: Continued - Males in the Private Sector

\begin{tabular}{|c|c|c|c|c|c|c|}
\hline \multirow[t]{2}{*}{ Variable } & \multicolumn{3}{|c|}{1991} & \multicolumn{3}{|c|}{2003} \\
\hline & $\begin{array}{c}\text { Union } \\
\text { Member }\end{array}$ & Non-member & $\begin{array}{c}\text { Not } \\
\text { covered }\end{array}$ & $\begin{array}{c}\text { Union } \\
\text { Member }\end{array}$ & $\begin{array}{c}\text { Non- } \\
\text { member }\end{array}$ & $\begin{array}{c}\text { Not } \\
\text { covered }\end{array}$ \\
\hline \multicolumn{7}{|l|}{ Employment characteristics } \\
\hline Industry: energy and water & 0.10 & 0.03 & 0.02 & 0.05 & 0.05 & 0.02 \\
\hline Industry: chemical & 0.11 & 0.04 & 0.04 & 0.06 & 0.03 & 0.02 \\
\hline Industry: engineering & 0.23 & 0.24 & 0.22 & 0.17 & 0.17 & 0.13 \\
\hline Industry: other manufacture & 0.21 & 0.21 & 0.15 & 0.17 & 0.15 & 0.11 \\
\hline Industry: construction & 0.03 & 0.08 & 0.09 & 0.08 & 0.09 & 0.10 \\
\hline Industry: distribution & 0.04 & 0.16 & 0.27 & 0.07 & 0.17 & 0.25 \\
\hline Industry: transport & 0.14 & 0.07 & 0.04 & 0.12 & 0.07 & 0.04 \\
\hline Industry: banking & 0.11 & 0.15 & 0.13 & 0.11 & 0.11 & 0.10 \\
\hline Industry: other services & 0.03 & 0.03 & 0.03 & 0.19 & 0.18 & 0.23 \\
\hline \multicolumn{7}{|l|}{ INSTRUMENTS } \\
\hline Party supporter & 0.44 & 0.42 & 0.38 & 0.35 & 0.29 & 0.28 \\
\hline \multicolumn{7}{|l|}{ Type of school attended } \\
\hline Comprehensive & 0.78 & 0.72 & 0.73 & 0.82 & 0.77 & 0.77 \\
\hline Grammar no fee & 0.11 & 0.13 & 0.13 & 0.07 & 0.07 & 0.08 \\
\hline Private school & 0.03 & 0.07 & 0.08 & 0.02 & 0.05 & 0.06 \\
\hline Technical school & 0.08 & 0.08 & 0.07 & 0.09 & 0.11 & 0.09 \\
\hline \multicolumn{7}{|l|}{ Household Information } \\
\hline House is owned & 0.83 & 0.81 & 0.76 & 0.84 & 0.81 & 0.78 \\
\hline House: City Council & 0.13 & 0.12 & 0.12 & 0.10 & 0.09 & 0.11 \\
\hline House is rented & 0.04 & 0.07 & 0.12 & 0.06 & 0.10 & 0.11 \\
\hline There is a child between 0 and 2 & 0.08 & 0.07 & 0.11 & 0.06 & 0.09 & 0.09 \\
\hline There is a child between 3 and 4 & 0.09 & 0.09 & 0.10 & 0.06 & 0.10 & 0.09 \\
\hline There is a child between 5 and 11 & 0.25 & 0.20 & 0.19 & 0.26 & 0.20 & 0.21 \\
\hline There is a child between 12 and 15 & 0.16 & 0.18 & 0.15 & 0.21 & 0.14 & 0.15 \\
\hline There is a child between 16 and 18 & 0.05 & 0.06 & 0.06 & 0.05 & 0.03 & 0.04 \\
\hline Partner employed & 0.64 & 0.49 & 0.49 & 0.62 & 0.54 & 0.57 \\
\hline \multicolumn{7}{|l|}{ Parental Background } \\
\hline Father: missing values & 0.11 & 0.10 & 0.08 & 0.20 & 0.28 & 0.26 \\
\hline Father: professional non manиal & 0.24 & 0.35 & 0.34 & 0.22 & 0.29 & 0.30 \\
\hline Father: skilled manual & 0.42 & 0.34 & 0.34 & 0.38 & 0.22 & 0.25 \\
\hline Father: semi skilled and unskilled & 0.16 & 0.13 & 0.13 & 0.12 & 0.11 & 0.10 \\
\hline Father: own occupation and other & 0.08 & 0.08 & 0.11 & 0.09 & 0.09 & 0.08 \\
\hline Mother: missing values & 0.47 & 0.48 & 0.50 & 0.51 & 0.56 & 0.51 \\
\hline Mother: professional non maпиаl & 0.28 & 0.34 & 0.30 & 0.31 & 0.28 & 0.33 \\
\hline Mother: skilled manиal & 0.05 & 0.03 & 0.03 & 0.04 & 0.02 & 0.02 \\
\hline Mother: semi skilled and unskilled & 0.17 & 0.13 & 0.13 & 0.12 & 0.11 & 0.11 \\
\hline Mother: own occupation and other & 0.03 & 0.01 & 0.04 & 0.02 & 0.03 & 0.03 \\
\hline \multicolumn{7}{|l|}{ Employment Information } \\
\hline Work not during business hours & 0.40 & 0.19 & 0.18 & 0.55 & 0.45 & 0.33 \\
\hline Work overtime & 0.59 & 0.57 & 0.57 & 0.54 & 0.55 & 0.55 \\
\hline Want to work fewer hours & 0.38 & 0.32 & 0.36 & 0.37 & 0.32 & 0.38 \\
\hline Works at workplace & 0.77 & 0.79 & 0.76 & 0.74 & 0.78 & 0.73 \\
\hline Remuneration scheme & 0.90 & 0.78 & 0.56 & 0.89 & 0.86 & 0.62 \\
\hline Bonus incentives & 0.45 & 0.46 & 0.38 & 0.42 & 0.36 & 0.40 \\
\hline Promotion opportunities at work & 0.64 & 0.70 & 0.49 & 0.59 & 0.68 & 0.45 \\
\hline Number of Observations & 475 & 195 & 792 & 399 & 321 & 1,181 \\
\hline
\end{tabular}




\section{APPENDIX: Table A3: Summary statistics - Mean (Standard deviation) Females in the Private Sector}

\begin{tabular}{|c|c|c|c|c|c|c|}
\hline \multirow[t]{2}{*}{ Variable } & \multicolumn{3}{|c|}{1991} & \multicolumn{3}{|c|}{2003} \\
\hline & $\begin{array}{c}\text { Union } \\
\text { Member }\end{array}$ & $\begin{array}{c}\text { Non- } \\
\text { member }\end{array}$ & $\begin{array}{c}\text { Not } \\
\text { covered }\end{array}$ & $\begin{array}{l}\text { Union } \\
\text { Member }\end{array}$ & $\begin{array}{c}\text { Non- } \\
\text { member }\end{array}$ & Not covered \\
\hline Ln (hourly wage) & $\begin{array}{c}1.82 \\
(0.38) \\
\end{array}$ & $\begin{array}{c}1.78 \\
(0.36) \\
\end{array}$ & $\begin{array}{c}1.60 \\
(0.49) \\
\end{array}$ & $\begin{array}{c}1.99 \\
(0.42) \\
\end{array}$ & $\begin{array}{c}1.88 \\
(0.44) \\
\end{array}$ & $\begin{array}{c}1.88 \\
(0.49) \\
\end{array}$ \\
\hline \multicolumn{7}{|l|}{ Individual information } \\
\hline Tenure (months) & $\begin{array}{l}74.48 \\
(81.73) \\
\end{array}$ & $\begin{array}{c}46.75 \\
(61.73) \\
\end{array}$ & $\begin{array}{c}51.41 \\
(65.33) \\
\end{array}$ & $\begin{array}{c}42.97 \\
(66.10) \\
\end{array}$ & $\begin{array}{c}25.10 \\
(32.76)\end{array}$ & $\begin{array}{c}30.11 \\
(47.34) \\
\end{array}$ \\
\hline Missing tenure & 0.22 & 0.20 & 0.15 & 0.33 & 0.18 & 0.21 \\
\hline Experience (months) & $\begin{array}{c}145.83 \\
(126.88) \\
\end{array}$ & $\begin{array}{c}131.27 \\
(121.06) \\
\end{array}$ & $\begin{array}{c}145.24 \\
(128.91) \\
\end{array}$ & $\begin{array}{c}81.49 \\
(131.33) \\
\end{array}$ & $\begin{array}{c}67.46 \\
(108.34) \\
\end{array}$ & $\begin{array}{c}83.05 \\
(126.19) \\
\end{array}$ \\
\hline Missing experience & 0.23 & 0.21 & 0.20 & 0.59 & 0.48 & 0.52 \\
\hline Training & 0.41 & 0.40 & 0.26 & 0.25 & 0.22 & 0.19 \\
\hline Married & 0.75 & 0.65 & 0.70 & 0.74 & 0.68 & 0.69 \\
\hline White & 0.97 & 0.97 & 0.98 & 0.96 & 0.96 & 0.96 \\
\hline Health limits work & 0.06 & 0.07 & 0.09 & 0.08 & 0.08 & 0.09 \\
\hline \multicolumn{7}{|l|}{ Qualification } \\
\hline Higher degree & 0.03 & 0.05 & 0.06 & 0.10 & 0.14 & 0.09 \\
\hline Other higher qualification & 0.13 & 0.12 & 0.11 & 0.28 & 0.29 & 0.32 \\
\hline 'A'Level & 0.12 & 0.15 & 0.10 & 0.18 & 0.19 & 0.15 \\
\hline 'O'Level & 0.32 & 0.34 & 0.34 & 0.26 & 0.21 & 0.23 \\
\hline Other qualification & 0.14 & 0.13 & 0.14 & 0.07 & 0.09 & 0.10 \\
\hline Apprentice & 0.00 & 0.00 & 0.00 & 0.00 & 0.01 & 0.00 \\
\hline No qualification at all & 0.25 & 0.21 & 0.25 & 0.12 & 0.07 & 0.11 \\
\hline \multicolumn{7}{|l|}{ Age } \\
\hline$<=25$ & 0.19 & 0.25 & 0.21 & 0.11 & 0.23 & 0.17 \\
\hline $25<=35$ & 0.31 & 0.30 & 0.30 & 0.25 & 0.32 & 0.25 \\
\hline $35<=45$ & 0.29 & 0.23 & 0.26 & 0.32 & 0.26 & 0.28 \\
\hline$>45$ & 0.21 & 0.23 & 0.24 & 0.31 & 0.19 & 0.29 \\
\hline \multicolumn{7}{|l|}{ Residential location } \\
\hline London & 0.06 & 0.11 & 0.11 & 0.04 & 0.04 & 0.06 \\
\hline South East & 0.13 & 0.23 & 0.22 & 0.12 & 0.12 & 0.16 \\
\hline South West & 0.06 & 0.07 & 0.09 & 0.08 & 0.07 & 0.07 \\
\hline East Anglia & 0.03 & 0.04 & 0.04 & 0.03 & 0.04 & 0.03 \\
\hline East Midlands & 0.07 & 0.09 & 0.08 & 0.05 & 0.07 & 0.07 \\
\hline West Midlands & 0.10 & 0.12 & 0.09 & 0.06 & 0.04 & 0.05 \\
\hline North West & 0.14 & 0.05 & 0.10 & 0.10 & 0.09 & 0.09 \\
\hline York & 0.12 & 0.12 & 0.10 & 0.08 & 0.09 & 0.06 \\
\hline North & 0.09 & 0.05 & 0.04 & 0.06 & 0.03 & 0.04 \\
\hline Wales & 0.07 & 0.04 & 0.04 & 0.16 & 0.14 & 0.17 \\
\hline Scotland & 0.13 & 0.08 & 0.08 & 0.22 & 0.26 & 0.20 \\
\hline $\begin{array}{l}\text { Travel-to-work-area } \\
\text { Unemployment rate }\end{array}$ & $\begin{array}{c}0.09 \\
(0.02)\end{array}$ & $\begin{array}{c}0.08 \\
(0.02)\end{array}$ & $\begin{array}{c}0.08 \\
(0.02)\end{array}$ & $\begin{array}{c}0.03 \\
(0.01)\end{array}$ & $\begin{array}{c}0.03 \\
(0.01)\end{array}$ & $\begin{array}{c}0.02 \\
(0.01)\end{array}$ \\
\hline \multicolumn{7}{|l|}{ Employment characteristics } \\
\hline Permanent contract & 0.98 & 0.95 & 0.92 & 0.99 & 0.93 & 0.97 \\
\hline Full time contract & 0.75 & 0.71 & 0.63 & 0.71 & 0.66 & 0.68 \\
\hline Firm size: 1-24 employees & 0.19 & 0.21 & 0.52 & 0.25 & 0.19 & 0.51 \\
\hline Firm size: $25-49$ employees & 0.12 & 0.09 & 0.14 & 0.11 & 0.10 & 0.14 \\
\hline Firm size: $50-99$ employees & 0.13 & 0.07 & 0.10 & 0.11 & 0.12 & 0.11 \\
\hline Firm size: >100 employees & 0.57 & 0.62 & 0.24 & 0.54 & 0.59 & 0.24 \\
\hline Occupation: prof \& manager & 0.09 & 0.08 & 0.13 & 0.20 & 0.18 & 0.23 \\
\hline Occupation: other non manual & 0.61 & 0.75 & 0.68 & 0.61 & 0.68 & 0.61 \\
\hline Occupation: skilled manual & 0.09 & 0.04 & 0.05 & 0.09 & 0.06 & 0.04 \\
\hline $\begin{array}{r}\text { Occupation: semi-skilled man \& } \\
\text { unskilled }\end{array}$ & 0.20 & 0.13 & 0.15 & 0.11 & 0.09 & 0.12 \\
\hline
\end{tabular}


Table A3: Continued - Females in the Private Sector

\begin{tabular}{|c|c|c|c|c|c|c|}
\hline \multirow[t]{2}{*}{ Variable } & \multicolumn{3}{|c|}{1991} & \multicolumn{3}{|c|}{2003} \\
\hline & $\begin{array}{c}\text { Union } \\
\text { Member }\end{array}$ & Non-member & $\begin{array}{c}\text { Not } \\
\text { covered }\end{array}$ & $\begin{array}{c}\text { Union } \\
\text { Member }\end{array}$ & $\begin{array}{c}\text { Non- } \\
\text { member }\end{array}$ & $\begin{array}{c}\text { Not } \\
\text { covered }\end{array}$ \\
\hline \multicolumn{7}{|l|}{ Employment characteristics } \\
\hline Industry: energy and water & 0.04 & 0.04 & 0.00 & 0.02 & 0.03 & 0.01 \\
\hline Industry: chemical & 0.03 & 0.05 & 0.03 & 0.01 & 0.02 & 0.01 \\
\hline Industry: engineering & 0.12 & 0.13 & 0.07 & 0.05 & 0.04 & 0.06 \\
\hline Industry: other manufacture & 0.16 & 0.17 & 0.13 & 0.11 & 0.10 & 0.09 \\
\hline Industry: construction & 0.00 & 0.00 & 0.01 & 0.00 & 0.01 & 0.03 \\
\hline Industry: distribution & 0.23 & 0.27 & 0.36 & 0.33 & 0.36 & 0.35 \\
\hline Industry: transport & 0.08 & 0.05 & 0.03 & 0.02 & 0.01 & 0.01 \\
\hline Industry: banking & 0.28 & 0.23 & 0.19 & 0.25 & 0.21 & 0.08 \\
\hline Industry: other services & 0.06 & 0.07 & 0.17 & 0.21 & 0.22 & 0.37 \\
\hline \multicolumn{7}{|l|}{ INSTRUMENTS } \\
\hline Party supporter & 0.29 & 0.30 & 0.34 & 0.29 & 0.19 & 0.24 \\
\hline \multicolumn{7}{|l|}{ Type of school attended } \\
\hline Comprehensive & 0.80 & 0.79 & 0.74 & 0.77 & 0.80 & 0.78 \\
\hline Grammar no fee & 0.11 & 0.10 & 0.12 & 0.08 & 0.07 & 0.09 \\
\hline Private school & 0.04 & 0.03 & 0.05 & 0.04 & 0.04 & 0.04 \\
\hline Technical school & 0.05 & 0.08 & 0.08 & 0.11 & 0.09 & 0.09 \\
\hline \multicolumn{7}{|l|}{ Household Information } \\
\hline House is owned & 0.81 & 0.79 & 0.74 & 0.82 & 0.80 & 0.76 \\
\hline House: City Council & 0.13 & 0.13 & 0.16 & 0.10 & 0.12 & 0.12 \\
\hline House is rented & 0.06 & 0.07 & 0.10 & 0.07 & 0.08 & 0.11 \\
\hline There is a child between 0 and 2 & 0.06 & 0.03 & 0.05 & 0.05 & 0.06 & 0.04 \\
\hline There is a child between 3 and 4 & 0.06 & 0.07 & 0.07 & 0.09 & 0.08 & 0.06 \\
\hline There is a child between 5 and 11 & 0.17 & 0.16 & 0.22 & 0.21 & 0.26 & 0.21 \\
\hline There is a child between 12 and 15 & 0.17 & 0.09 & 0.17 & 0.17 & 0.18 & 0.17 \\
\hline There is a child between 16 and 18 & 0.06 & 0.07 & 0.07 & 0.04 & 0.03 & 0.04 \\
\hline Partner employed & 0.72 & 0.58 & 0.64 & 0.67 & 0.62 & 0.62 \\
\hline \multicolumn{7}{|l|}{ Parental Background } \\
\hline Father: missing values & 0.10 & 0.13 & 0.10 & 0.20 & 0.32 & 0.27 \\
\hline Father: professional non manual & 0.30 & 0.29 & 0.30 & 0.29 & 0.26 & 0.25 \\
\hline Father: skilled manual & 0.39 & 0.37 & 0.33 & 0.29 & 0.21 & 0.27 \\
\hline Father: semi skilled and unskilled & 0.14 & 0.13 & 0.16 & 0.12 & 0.12 & 0.10 \\
\hline Father: own occupation and other & 0.07 & 0.09 & 0.11 & 0.10 & 0.09 & 0.10 \\
\hline Mother: missing values & 0.44 & 0.54 & 0.46 & 0.45 & 0.52 & 0.47 \\
\hline Mother: professional non manual & 0.35 & 0.30 & 0.32 & 0.36 & 0.31 & 0.33 \\
\hline Mother: skilled manual & 0.05 & 0.05 & 0.04 & 0.04 & 0.02 & 0.04 \\
\hline Mother: semi skilled and unskilled & 0.14 & 0.09 & 0.15 & 0.12 & 0.12 & 0.13 \\
\hline Mother: own occupation and other & 0.03 & 0.02 & 0.03 & 0.03 & 0.02 & 0.03 \\
\hline \multicolumn{7}{|l|}{ Employment Information } \\
\hline Work not during business hours & 0.27 & 0.28 & 0.35 & 0.38 & 0.38 & 0.34 \\
\hline Work overtime & 0.39 & 0.31 & 0.34 & 0.41 & 0.46 & 0.37 \\
\hline Want to work less hours & 0.29 & 0.25 & 0.27 & 0.34 & 0.28 & 0.35 \\
\hline Works at workplace & 0.98 & 0.97 & 0.91 & 0.92 & 0.94 & 0.91 \\
\hline Remuneration scheme & 0.89 & 0.76 & 0.35 & 0.92 & 0.85 & 0.54 \\
\hline Bonus incentives & 0.49 & 0.42 & 0.24 & 0.49 & 0.40 & 0.36 \\
\hline Promotion opportunities at work & 0.61 & 0.60 & 0.32 & 0.70 & 0.63 & 0.39 \\
\hline Number of Observations & 236 & 151 & 820 & 228 & 250 & 988 \\
\hline
\end{tabular}


APPENDIX: Table A4: Summary statistics - Mean (Standard deviation) Males in the Public Sector

\begin{tabular}{|c|c|c|c|c|c|c|}
\hline \multirow[t]{2}{*}{ Variable } & \multicolumn{3}{|c|}{1991} & \multicolumn{3}{|c|}{2003} \\
\hline & $\begin{array}{c}\text { Union } \\
\text { Member }\end{array}$ & $\begin{array}{c}\text { Non- } \\
\text { member }\end{array}$ & $\begin{array}{c}\text { Not } \\
\text { covered }\end{array}$ & $\begin{array}{l}\text { Union } \\
\text { Member }\end{array}$ & $\begin{array}{c}\text { Non- } \\
\text { member }\end{array}$ & Not covered \\
\hline Ln (hourly wage) & $\begin{array}{c}2.24 \\
(0.40) \\
\end{array}$ & $\begin{array}{c}2.21 \\
(0.41) \\
\end{array}$ & $\begin{array}{c}1.89 \\
(0.71) \\
\end{array}$ & $\begin{array}{c}2.42 \\
(0.43) \\
\end{array}$ & $\begin{array}{c}2.27 \\
(0.46) \\
\end{array}$ & $\begin{array}{c}1.99 \\
(0.45) \\
\end{array}$ \\
\hline \multicolumn{7}{|l|}{ Individual information } \\
\hline Tenure (months) & $\begin{array}{c}105.52 \\
(111.87) \\
\end{array}$ & $\begin{array}{c}58.85 \\
(77.55) \\
\end{array}$ & $\begin{array}{c}84.77 \\
(110.43) \\
\end{array}$ & $\begin{array}{l}51.40 \\
(89.60)\end{array}$ & $\begin{array}{c}25.27 \\
(48.54) \\
\end{array}$ & $\begin{array}{c}31.59 \\
(64.26) \\
\end{array}$ \\
\hline Missing tenure & 0.23 & 0.15 & 0.23 & 0.45 & 0.32 & 0.30 \\
\hline Experience (months) & $\begin{array}{c}186.24 \\
(158.18) \\
\end{array}$ & $\begin{array}{c}187.16 \\
(155.43) \\
\end{array}$ & $\begin{array}{c}162.11 \\
(148.46)\end{array}$ & $\begin{array}{c}105.80 \\
(154.30) \\
\end{array}$ & $\begin{array}{c}76.97 \\
(137.45) \\
\end{array}$ & $\begin{array}{c}91.76 \\
(163.03) \\
\end{array}$ \\
\hline Missing experience & 0.25 & 0.18 & 0.23 & 0.58 & 0.61 & 0.57 \\
\hline Training & 0.54 & 0.55 & 0.52 & 0.36 & 0.35 & 0.14 \\
\hline Married & 0.77 & 0.69 & 0.65 & 0.76 & 0.67 & 0.70 \\
\hline White & 0.97 & 0.96 & 1.00 & 0.95 & 0.95 & 0.93 \\
\hline Health limits work & 0.06 & 0.08 & 0.03 & 0.08 & 0.04 & 0.09 \\
\hline \multicolumn{7}{|l|}{ Qualification } \\
\hline Higher degree & 0.22 & 0.22 & 0.42 & 0.34 & 0.32 & 0.26 \\
\hline Other higher qualification & 0.26 & 0.33 & 0.19 & 0.38 & 0.39 & 0.36 \\
\hline 'A'Level & 0.15 & 0.07 & 0.06 & 0.07 & 0.12 & 0.10 \\
\hline 'O'Level & 0.16 & 0.20 & 0.23 & 0.12 & 0.09 & 0.17 \\
\hline Other qualification & 0.04 & 0.05 & 0.00 & 0.03 & 0.02 & 0.02 \\
\hline Apprentice & 0.02 & 0.02 & 0.03 & 0.00 & 0.00 & 0.00 \\
\hline No qualification at all & 0.15 & 0.11 & 0.06 & 0.05 & 0.06 & 0.10 \\
\hline \multicolumn{7}{|l|}{ Age } \\
\hline$<=25$ & 0.08 & 0.13 & 0.19 & 0.03 & 0.11 & 0.14 \\
\hline $25<=35$ & 0.30 & 0.29 & 0.16 & 0.20 & 0.27 & 0.27 \\
\hline $35<=45$ & 0.29 & 0.31 & 0.32 & 0.34 & 0.36 & 0.18 \\
\hline$>45$ & 0.33 & 0.27 & 0.32 & 0.43 & 0.25 & 0.41 \\
\hline \multicolumn{7}{|l|}{ Residential location } \\
\hline London & 0.13 & 0.21 & 0.29 & 0.07 & 0.09 & 0.11 \\
\hline South East & 0.17 & 0.15 & 0.13 & 0.11 & 0.13 & 0.27 \\
\hline South West & 0.07 & 0.14 & 0.06 & 0.04 & 0.05 & 0.02 \\
\hline East Anglia & 0.02 & 0.01 & 0.06 & 0.02 & 0.00 & 0.05 \\
\hline East Midlands & 0.07 & 0.06 & 0.03 & 0.05 & 0.09 & 0.00 \\
\hline West Midlands & 0.09 & 0.08 & 0.03 & 0.07 & 0.02 & 0.00 \\
\hline North West & 0.10 & 0.05 & 0.10 & 0.07 & 0.06 & 0.05 \\
\hline Yorkshire and Humberside & 0.11 & 0.08 & 0.10 & 0.04 & 0.05 & 0.07 \\
\hline North & 0.07 & 0.04 & 0.13 & 0.05 & 0.03 & 0.05 \\
\hline Wales & 0.06 & 0.06 & 0.03 & 0.19 & 0.19 & 0.14 \\
\hline Scotland & 0.11 & 0.12 & 0.03 & 0.29 & 0.28 & 0.25 \\
\hline $\begin{array}{l}\text { Travel-to-work-area } \\
\text { Unemployment rate }\end{array}$ & $\begin{array}{c}0.08 \\
(0.02)\end{array}$ & $\begin{array}{c}0.08 \\
(0.02)\end{array}$ & $\begin{array}{c}0.08 \\
(0.02)\end{array}$ & $\begin{array}{c}0.03 \\
(0.01)\end{array}$ & $\begin{array}{c}0.02 \\
(0.01)\end{array}$ & $\begin{array}{c}0.02 \\
(0.01)\end{array}$ \\
\hline \multicolumn{7}{|l|}{ Employment characteristics } \\
\hline Permanent contract & 0.96 & 0.87 & 0.87 & 0.99 & 0.93 & 0.93 \\
\hline Full time contract & 0.99 & 0.95 & 0.90 & 0.98 & 0.94 & 0.84 \\
\hline Firm size: 1-24 employees & 0.13 & 0.21 & 0.42 & 0.15 & 0.25 & 0.50 \\
\hline Firm size: $25-49$ employees & 0.12 & 0.09 & 0.13 & 0.09 & 0.09 & 0.16 \\
\hline Firm size: $50-99$ employees & 0.15 & 0.14 & 0.16 & 0.19 & 0.08 & 0.11 \\
\hline Firm size: >100 employees & 0.60 & 0.55 & 0.29 & 0.57 & 0.57 & 0.23 \\
\hline Occupation: prof \& manager & 0.26 & 0.28 & 0.55 & 0.32 & 0.26 & 0.34 \\
\hline Occupation: other non manual & 0.42 & 0.52 & 0.26 & 0.42 & 0.49 & 0.34 \\
\hline Occupation: skilled manual & 0.19 & 0.11 & 0.06 & 0.12 & 0.09 & 0.18 \\
\hline $\begin{array}{r}\text { Occupation: semi-skilled man \& } \\
\text { unskilled }\end{array}$ & 0.13 & 0.09 & 0.13 & 0.14 & 0.16 & 0.14 \\
\hline
\end{tabular}


Table A4: Continued - Males in the Public Sector

\begin{tabular}{|c|c|c|c|c|c|c|}
\hline \multirow[t]{2}{*}{ Variable } & \multicolumn{3}{|c|}{1991} & \multicolumn{3}{|c|}{2003} \\
\hline & $\begin{array}{c}\text { Union } \\
\text { Member }\end{array}$ & Non-member & $\begin{array}{c}\text { Not } \\
\text { covered }\end{array}$ & $\begin{array}{c}\text { Union } \\
\text { Member }\end{array}$ & $\begin{array}{c}\text { Non- } \\
\text { member }\end{array}$ & $\begin{array}{c}\text { Not } \\
\text { covered }\end{array}$ \\
\hline \multicolumn{7}{|l|}{ Employment characteristics } \\
\hline Industry: energy and water & 0.05 & 0.00 & 0.03 & 0.01 & 0.00 & 0.00 \\
\hline Industry: chemical & 0.00 & 0.01 & 0.03 & 0.00 & 0.00 & 0.00 \\
\hline Industry: engineering & 0.01 & 0.02 & 0.00 & 0.01 & 0.00 & 0.00 \\
\hline Industry: other manufacture & 0.00 & 0.02 & 0.03 & 0.01 & 0.00 & 0.00 \\
\hline Industry: construction & 0.06 & 0.06 & 0.00 & 0.03 & 0.03 & 0.02 \\
\hline Industry: distribution & 0.01 & 0.01 & 0.06 & 0.00 & 0.02 & 0.07 \\
\hline Industry: transport & 0.15 & 0.05 & 0.00 & 0.01 & 0.00 & 0.00 \\
\hline Industry: banking & 0.04 & 0.05 & 0.16 & 0.00 & 0.03 & 0.07 \\
\hline Industry: other services & 0.68 & 0.78 & 0.68 & 0.92 & 0.92 & 0.84 \\
\hline \multicolumn{7}{|l|}{ INSTRUMENTS } \\
\hline Party supporter & 0.52 & 0.46 & 0.45 & 0.38 & 0.34 & 0.30 \\
\hline \multicolumn{7}{|l|}{ Type of school attended } \\
\hline Comprehensive & 0.67 & 0.61 & 0.58 & 0.71 & 0.69 & 0.68 \\
\hline Grammar no fee & 0.21 & 0.21 & 0.29 & 0.14 & 0.12 & 0.11 \\
\hline Private school & 0.05 & 0.08 & 0.06 & 0.06 & 0.06 & 0.07 \\
\hline Technical school & 0.07 & 0.09 & 0.06 & 0.09 & 0.12 & 0.14 \\
\hline \multicolumn{7}{|l|}{ Household Information } \\
\hline House is owned & 0.83 & 0.81 & 0.58 & 0.88 & 0.75 & 0.59 \\
\hline House: City Council & 0.09 & 0.08 & 0.13 & 0.07 & 0.09 & 0.14 \\
\hline House is rented & 0.08 & 0.11 & 0.29 & 0.05 & 0.16 & 0.27 \\
\hline There is a child between 0 and 2 & 0.10 & 0.13 & 0.06 & 0.08 & 0.07 & 0.05 \\
\hline There is a child between 3 and 4 & 0.10 & 0.06 & 0.10 & 0.10 & 0.09 & 0.07 \\
\hline There is a child between 5 and 11 & 0.19 & 0.13 & 0.26 & 0.24 & 0.20 & 0.16 \\
\hline There is a child between 12 and 15 & 0.12 & 0.13 & 0.39 & 0.19 & 0.14 & 0.09 \\
\hline There is a child between 16 and 18 & 0.08 & 0.06 & 0.13 & 0.06 & 0.04 & 0.02 \\
\hline Partner employed & 0.60 & 0.59 & 0.39 & 0.64 & 0.57 & 0.66 \\
\hline \multicolumn{7}{|l|}{ Parental Background } \\
\hline Father: missing values & 0.07 & 0.05 & 0.13 & 0.10 & 0.22 & 0.25 \\
\hline Father: professional non manual & 0.33 & 0.44 & 0.55 & 0.39 & 0.34 & 0.45 \\
\hline Father: skilled manual & 0.34 & 0.35 & 0.13 & 0.30 & 0.29 & 0.14 \\
\hline Father: semi skilled and unskilled & 0.16 & 0.11 & 0.10 & 0.15 & 0.07 & 0.11 \\
\hline Father: own occupation and other & 0.10 & 0.06 & 0.10 & 0.06 & 0.09 & 0.05 \\
\hline Mother: missing values & 0.48 & 0.52 & 0.58 & 0.44 & 0.52 & 0.59 \\
\hline Mother: professional non manual & 0.37 & 0.28 & 0.32 & 0.38 & 0.37 & 0.34 \\
\hline Mother: skilled manual & 0.03 & 0.04 & 0.00 & 0.02 & 0.02 & 0.00 \\
\hline Mother: semi skilled and unskilled & 0.10 & 0.15 & 0.10 & 0.14 & 0.07 & 0.05 \\
\hline Mother: own occupation and other & 0.02 & 0.01 & 0.00 & 0.01 & 0.02 & 0.02 \\
\hline \multicolumn{7}{|l|}{ Employment Information } \\
\hline Work not during business hours & 0.38 & 0.27 & 0.35 & 0.38 & 0.28 & 0.41 \\
\hline Work overtime & 0.57 & 0.41 & 0.55 & 0.48 & 0.48 & 0.48 \\
\hline Want to work less hours & 0.35 & 0.26 & 0.29 & 0.35 & 0.28 & 0.32 \\
\hline Works at workplace & 0.69 & 0.76 & 0.74 & 0.76 & 0.79 & 0.77 \\
\hline Remuneration scheme & 0.98 & 0.89 & 0.58 & 0.99 & 0.97 & 0.73 \\
\hline Bonus incentives & 0.26 & 0.24 & 0.07 & 0.19 & 0.12 & 0.14 \\
\hline Promotion opportunities at work & 0.82 & 0.69 & 0.39 & 0.71 & 0.63 & 0.39 \\
\hline Number of Observations & 335 & 85 & 31 & 343 & 161 & 44 \\
\hline
\end{tabular}




\section{APPENDIX: Table A5: Summary statistics - Mean (Standard deviation) Females in the Public Sector}

\begin{tabular}{|c|c|c|c|c|c|c|}
\hline \multirow[t]{2}{*}{ Variable } & \multicolumn{3}{|c|}{1991} & \multicolumn{3}{|c|}{2003} \\
\hline & $\begin{array}{c}\text { Union } \\
\text { Member }\end{array}$ & $\begin{array}{c}\text { Non- } \\
\text { member }\end{array}$ & $\begin{array}{c}\text { Not } \\
\text { covered }\end{array}$ & $\begin{array}{l}\text { Union } \\
\text { Member }\end{array}$ & $\begin{array}{c}\text { Non- } \\
\text { member }\end{array}$ & Not covered \\
\hline Ln (hourly wage) & $\begin{array}{c}2.07 \\
(0.43) \\
\end{array}$ & $\begin{array}{c}1.88 \\
(0.44) \\
\end{array}$ & $\begin{array}{c}1.67 \\
(0.50) \\
\end{array}$ & $\begin{array}{c}2.27 \\
(0.39) \\
\end{array}$ & $\begin{array}{c}2.08 \\
(0.43) \\
\end{array}$ & $\begin{array}{c}1.89 \\
(0.45) \\
\end{array}$ \\
\hline \multicolumn{7}{|l|}{ Individual information } \\
\hline Tenure (months) & $\begin{array}{c}80.08 \\
(85.57) \\
\end{array}$ & $\begin{array}{l}54.16 \\
(65.50)\end{array}$ & $\begin{array}{c}60.84 \\
(68.77) \\
\end{array}$ & $\begin{array}{l}43.30 \\
(70.78) \\
\end{array}$ & $\begin{array}{c}35.43 \\
(62.82) \\
\end{array}$ & $\begin{array}{l}35.95 \\
(56.92) \\
\end{array}$ \\
\hline Missing tenure & 0.21 & 0.15 & 0.09 & 0.34 & 0.23 & 0.17 \\
\hline Experience (months) & $\begin{array}{c}161.56 \\
(129.74) \\
\end{array}$ & $\begin{array}{c}165.59 \\
(127.78) \\
\end{array}$ & $\begin{array}{c}159.95 \\
(121.43) \\
\end{array}$ & $\begin{array}{c}90.74 \\
(136.14) \\
\end{array}$ & $\begin{array}{c}99.73 \\
(137.22) \\
\end{array}$ & $\begin{array}{c}93.68 \\
(135.16) \\
\end{array}$ \\
\hline Missing experience & 0.21 & 0.17 & 0.12 & 0.57 & 0.51 & 0.55 \\
\hline Training & 0.53 & 0.39 & 0.31 & 0.41 & 0.33 & 0.34 \\
\hline Married & 0.75 & 0.76 & 0.75 & 0.78 & 0.72 & 0.73 \\
\hline White & 0.94 & 0.98 & 0.98 & 0.96 & 0.91 & 0.93 \\
\hline Health limits work & 0.08 & 0.06 & 0.11 & 0.07 & 0.08 & 0.09 \\
\hline \multicolumn{7}{|l|}{ Qualification } \\
\hline Higher degree & 0.20 & 0.12 & 0.09 & 0.33 & 0.25 & 0.20 \\
\hline Other higher qualification & 0.34 & 0.23 & 0.25 & 0.41 & 0.35 & 0.35 \\
\hline 'A'Level & 0.08 & 0.08 & 0.11 & 0.08 & 0.12 & 0.09 \\
\hline 'O'Level & 0.18 & 0.30 & 0.25 & 0.10 & 0.18 & 0.16 \\
\hline Other qualification & 0.04 & 0.06 & 0.08 & 0.03 & 0.04 & 0.07 \\
\hline Apprentice & 0.00 & 0.01 & 0.00 & 0.00 & 0.00 & 0.00 \\
\hline No qualification at all & 0.15 & 0.20 & 0.22 & 0.04 & 0.06 & 0.13 \\
\hline \multicolumn{7}{|l|}{ Age } \\
\hline$<=25$ & 0.08 & 0.07 & 0.11 & 0.06 & 0.08 & 0.05 \\
\hline $25<=35$ & 0.29 & 0.24 & 0.24 & 0.22 & 0.21 & 0.18 \\
\hline $35<=45$ & 0.31 & 0.36 & 0.32 & 0.35 & 0.34 & 0.37 \\
\hline$>45$ & 0.32 & 0.33 & 0.33 & 0.38 & 0.37 & 0.40 \\
\hline \multicolumn{7}{|l|}{ Residential location } \\
\hline London & 0.11 & 0.16 & 0.14 & 0.05 & 0.10 & 0.06 \\
\hline South East & 0.12 & 0.20 & 0.20 & 0.10 & 0.17 & 0.19 \\
\hline South West & 0.04 & 0.06 & 0.09 & 0.03 & 0.07 & 0.07 \\
\hline East Anglia & 0.02 & 0.04 & 0.05 & 0.02 & 0.02 & 0.03 \\
\hline East Midlands & 0.06 & 0.09 & 0.03 & 0.06 & 0.06 & 0.03 \\
\hline West Midlands & 0.11 & 0.07 & 0.11 & 0.05 & 0.06 & 0.06 \\
\hline North West & 0.13 & 0.12 & 0.08 & 0.08 & 0.07 & 0.05 \\
\hline Yorkshire and Humberside & 0.12 & 0.07 & 0.04 & 0.08 & 0.06 & 0.04 \\
\hline North & 0.10 & 0.06 & 0.10 & 0.05 & 0.05 & 0.02 \\
\hline Wales & 0.07 & 0.04 & 0.04 & 0.22 & 0.14 & 0.21 \\
\hline Scotland & 0.13 & 0.10 & 0.10 & 0.26 & 0.20 & 0.23 \\
\hline $\begin{array}{l}\text { Travel-to-work-area } \\
\text { Unemployment rate }\end{array}$ & $\begin{array}{c}0.09 \\
(0.02)\end{array}$ & $\begin{array}{c}0.08 \\
(0.02)\end{array}$ & $\begin{array}{c}0.08 \\
(0.02)\end{array}$ & $\begin{array}{c}0.03 \\
(0.01)\end{array}$ & $\begin{array}{c}0.02 \\
(0.01)\end{array}$ & $\begin{array}{c}0.02 \\
(0.01)\end{array}$ \\
\hline \multicolumn{7}{|l|}{ Employment characteristics } \\
\hline Permanent contract & 0.93 & 0.81 & 0.89 & 0.96 & 0.95 & 0.93 \\
\hline Full time contract & 0.76 & 0.48 & 0.43 & 0.74 & 0.60 & 0.47 \\
\hline Firm size: 1-24 employees & 0.27 & 0.34 & 0.68 & 0.25 & 0.26 & 0.62 \\
\hline Firm size: $25-49$ employees & 0.14 & 0.3 & 0.12 & 0.19 & 0.15 & 0.16 \\
\hline Firm size: $50-99$ employees & 0.11 & 0.14 & 0.09 & 0.14 & 0.09 & 0.10 \\
\hline Firm size: >100 employees & 0.47 & 0.39 & 0.11 & 0.42 & 0.51 & 0.13 \\
\hline Occupation: prof \& manager & 0.18 & 0.11 & 0.12 & 0.22 & 0.15 & 0.23 \\
\hline Occupation: other non manual & 0.68 & 0.75 & 0.72 & 0.70 & 0.73 & 0.62 \\
\hline Occupation: skilled manual & 0.0 & 0.03 & 0.00 & 0.01 & 0.01 & 0.01 \\
\hline $\begin{array}{r}\text { Occupation: semi-skilled man \& } \\
\text { unskilled }\end{array}$ & 0.11 & 0.11 & 0.15 & 0.07 & 0.11 & 0.13 \\
\hline
\end{tabular}


Table A5: Continued - Females in the Public Sector

\begin{tabular}{|c|c|c|c|c|c|c|}
\hline \multirow[t]{2}{*}{ Variable } & \multicolumn{3}{|c|}{1991} & \multicolumn{3}{|c|}{2003} \\
\hline & $\begin{array}{c}\text { Union } \\
\text { Member }\end{array}$ & Non-member & $\begin{array}{c}\text { Not } \\
\text { covered }\end{array}$ & $\begin{array}{c}\text { Union } \\
\text { Member }\end{array}$ & $\begin{array}{c}\text { Non- } \\
\text { member }\end{array}$ & $\begin{array}{c}\text { Not } \\
\text { covered }\end{array}$ \\
\hline \multicolumn{7}{|l|}{ Employment characteristics } \\
\hline Industry: energy and water & 0.00 & 0.00 & 0.00 & 0.00 & 0.00 & 0.00 \\
\hline Industry: chemical & 0.00 & 0.00 & 0.00 & 0.00 & 0.00 & 0.00 \\
\hline Industry: engineering & 0.00 & 0.00 & 0.00 & 0.00 & 0.00 & 0.00 \\
\hline Industry: other manufacture & 0.00 & 0.00 & 0.00 & 0.00 & 0.00 & 0.00 \\
\hline Industry: construction & 0.00 & 0.00 & 0.01 & 0.00 & 0.00 & 0.00 \\
\hline Industry: distribution & 0.00 & 0.02 & 0.02 & 0.01 & 0.01 & 0.06 \\
\hline Industry: transport & 0.02 & 0.02 & 0.00 & 0.00 & 0.00 & 0.00 \\
\hline Industry: banking & 0.00 & 0.00 & 0.02 & 0.01 & 0.01 & 0.03 \\
\hline Industry: other services & 0.98 & 0.94 & 0.96 & 0.97 & 0.97 & 0.90 \\
\hline \multicolumn{7}{|l|}{ INSTRUMENTS } \\
\hline Party supporter & 0.45 & 0.39 & 0.33 & 0.32 & 0.31 & 0.28 \\
\hline \multicolumn{7}{|l|}{ Type of school attended } \\
\hline Comprehensive & 0.59 & 0.61 & 0.62 & 0.74 & 0.70 & 0.74 \\
\hline Grammar no fee & 0.24 & 0.23 & 0.22 & 0.13 & 0.15 & 0.09 \\
\hline Private school & 0.07 & 0.08 & 0.07 & 0.04 & 0.05 & 0.06 \\
\hline Technical school & 0.09 & 0.07 & 0.09 & 0.09 & 0.10 & 0.11 \\
\hline \multicolumn{7}{|l|}{ Household Information } \\
\hline House is owned & 0.80 & 0.82 & 0.76 & 0.88 & 0.82 & 0.77 \\
\hline House: City Council & 0.13 & 0.13 & 0.17 & 0.06 & 0.10 & 0.12 \\
\hline House is rented & 0.07 & 0.05 & 0.07 & 0.06 & 0.08 & 0.11 \\
\hline There is a child between 0 and 2 & 0.06 & 0.05 & 0.05 & 0.05 & 0.04 & 0.07 \\
\hline There is a child between 3 and 4 & 0.06 & 0.07 & 0.06 & 0.07 & 0.08 & 0.07 \\
\hline There is a child between 5 and 11 & 0.16 & 0.26 & 0.25 & 0.24 & 0.24 & 0.30 \\
\hline There is a child between 12 and 15 & 0.17 & 0.18 & 0.24 & 0.17 & 0.21 & 0.24 \\
\hline There is a child between 16 and 18 & 0.06 & 0.09 & 0.10 & 0.06 & 0.08 & 0.10 \\
\hline Partner employed & 0.67 & 0.67 & 0.66 & 0.71 & 0.67 & 0.68 \\
\hline \multicolumn{7}{|l|}{ Parental Background } \\
\hline Father: missing values & 0.10 & 0.10 & 0.12 & 0.16 & 0.17 & 0.17 \\
\hline Father: professional non mапиаl & 0.35 & 0.38 & 0.37 & 0.35 & 0.32 & 0.36 \\
\hline Father: skilled manual & 0.29 & 0.28 & 0.27 & 0.26 & 0.31 & 0.24 \\
\hline Father: semi skilled and unskilled & 0.16 & 0.14 & 0.13 & 0.13 & 0.09 & 0.10 \\
\hline Father: own occupation and other & 0.09 & 0.11 & 0.11 & 0.09 & 0.10 & 0.14 \\
\hline Mother: missing values & 0.45 & 0.49 & 0.47 & 0.41 & 0.44 & 0.52 \\
\hline Mother: professional non manual & 0.35 & 0.33 & 0.35 & 0.43 & 0.38 & 0.31 \\
\hline Mother: skilled manual & 0.04 & 0.02 & 0.03 & 0.02 & 0.02 & 0.03 \\
\hline Mother: semi skilled and unskilled & 0.14 & 0.11 & 0.14 & 0.12 & 0.14 & 0.12 \\
\hline Mother: own occupation and other & 0.03 & 0.04 & 0.03 & 002 & 0.02 & 0.02 \\
\hline \multicolumn{7}{|l|}{ Employment Information } \\
\hline Work not during business hours & 0.34 & 0.42 & 0.52 & 0.30 & 0.33 & 0.30 \\
\hline Work overtime & 0.41 & 0.25 & 0.27 & 0.48 & 0.34 & 0.38 \\
\hline Want to work less hours & 0.33 & 0.23 & 0.15 & 0.39 & 0.28 & 0.26 \\
\hline Works at workplace & 0.87 & 0.89 & 0.89 & 0.85 & 0.89 & 0.86 \\
\hline Remuneration scheme & 0.93 & 0.76 & 0.31 & 0.98 & 0.98 & 0.63 \\
\hline Bonus incentives & 0.10 & 0.10 & 0.04 & 0.07 & 0.08 & 0.17 \\
\hline Promotion opportunities at work & 0.63 & 0.44 & 0.27 & 0.61 & 0.26 & 0.28 \\
\hline Number of Observations & 449 & 227 & 118 & 703 & 344 & 178 \\
\hline
\end{tabular}

Note to Tables A1-A5: Control variables are denoted by normal case and instruments by

italics. 